УДК 622.807

DOI: https://doi.org/10.26642/ten-2021-2(88)-148-167

С.С. Руднсв, к.т.н., доц.

В.А. Гальченко, аспірант

Е.М. Філатьсва, ст. викладач

М.I. Антощенко, д.т.н., проф.

Східноукраӥнський нащіональний університет імені Володимира Даля

\title{
Про методику вибору показників для прогнозування небезпечних властивостей вугільних шахтопластів
}

\begin{abstract}
Небезпечні властивості вугільних пластів полягають у виникненні явищ, щио сприяють створенню аварійних ситуацій у підземних умовах з важкими наслідками для здоров'я та життя прачюючих, а також призводить до значних економічних збитків. Аналіз причин аварій, які вже відбулися, та нормативних вимог щчодо забезпечення безпеки технологічних прочесів показав, щзо всі аварії є наслідком комплексного впливу факторів трьох блоків (фізико-хімічні властивості вугілля, гірничо-геологічні умови залягання вугільних пластів та технологічні умови ведення гірничих робіт). Для виникнення ситуації, щзо сприяе прояву однієї з небезпечних властивостей вугільного шахтопласта і створенню умов для ініціювання та протікання аварії, необхідно деяке критичне сполучення між параметрами факторів усіх трьох блоків. Труднощі вивчення впливу окремих факторів на виникнення аварійних ситуачій полягає в неможливості, серед більшості випадків, повторного їх відтворення. Єдиним винятком з иього правила $\epsilon$ пилоутворювальна здатність шахтопластів. У нормативній базі Украӥни по безпечному веденню гірничих робіт відсутня методика кількісної оцінки впливу факторів різних блоків, поєднання яких призводить до аварійних ситуачій. Дослідження в цьому напрямі є дуже актуальними для вугільної промисловості. На прикладі статистичних моделей розподілу шахтопластів за факторами, на підставі яких складено каталог їх пилоутворювальної здатності, встановлено ступінь достовірності та відповідність изих факторів розглянутої властивості. Наведено практичні рекомендації щчодо удосконалення нормативних документів при прогнозі інших небезпечних властивостей шахтопластів.

Ключові слова: вугільні пласти; гірничі роботи; газовиділення; займання; вибухи; пожежі; пилоутворення; аварії; фактори; нормативна база; удосконалення.
\end{abstract}

Актуальність теми. Складні гірничо-геологічні умови вугільних родовищ України зумовили наявність великої кількості небезпечних і шкідливих супутніх гірничому виробництву чинників, які призводять до високого рівня травматизму. За останні кілька десятиліть відбулося понад сорок аварій 3 груповим травматизмом. Така тенденція зберігається і в наш час. Наведені факти свідчать, що актуальними є науково-дослідні роботи, направлені на створення безпечних умов відробки вугільних пластів.

Аналіз останніх досліджень та публікацій, на які спираються автори. Частина сучасної нормативної бази України по безпечному веденню гірничих робіт представлена діючими в даний час правилами, керівництвами, інструкціями та стандартами [1-9], в яких для прогнозу небезпечних властивостей шахтопластів використовується обмежена кількість факторів, що визначають ступінь їх метаморфічних перетворень при геологічних процесах. Відомі методики випробування вугілля [9, 11-13, $20,21]$ розроблені для встановлення споживчих властивостей та здебільшого вони відображають тільки властивості органічної (горючої) маси на сухий беззольний стан і не враховують наявність вологи та мінеральних домішок. Важливість застосування показників, які характеризують природний стан шахтопластів, відображена у роботах В.М. Опаріна [15], Я.С. Баляєвої [16], Л.Ф. Бутузової [17], Н.І. Федорової [18], І.Л. Еттінгера [19], С.Д. Ганової [23], Б.І. Кошовського [24], Е.М. Медведєва [25].

Ідея - вивчаючи процеси пилоутворення і встановлюючи вплив на них факторів, можна в цілому судити про можливі прояви інших небезпечних властивостей шахтопластів при веденні гірничих робіт під впливом цих же факторів.

Мета роботи - встановити кількісні параметри факторів трьох блоків, що визначають пилоутворювальну здатність вугільних шахтопластів і на їх основі дати пропозиції щодо розробки методики вибору показників для прогнозування інших небезпечних властивостей при веденні гірничих робіт.

Методикою проведення досліджень враховували, що пилоутворювальна здатність піддається кількісній оцінці залежно від факторів, що впливають. Це дає можливість, на підставі статистичних моделей, оцінити їх вплив. Вихідними даними для побудови статистичних моделей послугували експериментальні дані «Каталогу шахтопластів СРСР за пиловим фактором» [4], в якому наведено відомості більш ніж для двох тисяч розглянутих об'єктів.

Викладення основного матеріалу. Небезпечні властивості вугільних пластів виявляються при веденні гірничих робіт. У багатьох випадках їх супроводжують аварії в підземних умовах 3 важкими наслідками для здоров'я та життя працюючих, що також призводить до значних економічних збитків. 
Небезпечні властивості вугільних пластів полягають у виникненні явищ, що сприяють створенню аварійних ситуацій або супроводжують аварії, які вже відбулися. До найбільш небезпечних явищ належать виділення вибухових та легкозаймистих газів, раптове руйнування порід підошви 3 інтенсивним виділенням метану, виникнення вогнищ самозаймання вугілля, підвищене утворення пилу i його вибуховість та деякі інші негативні явища, які ускладнюють виробництво гірничих робіт у підземних умовах.

Гірничі роботи, незалежно від наявності або відсутності зазначених небезпечних властивостей шахтопластів, належать до виробничих процесів підвищеної небезпеки. У всіх випадках вони провадяться 3 дотриманням загальних правил безпеки. При встановленні одного або декількох небезпечних властивостей шахтопласта його відпрацювання регламентується низкою додаткових нормативних документів [1-8].

Аналіз причин аварій, які вже відбулися, та нормативних вимог щодо гарантування безпеки технологічних процесів [1-8] показав, що всі аварії є наслідком комплексного впливу факторів трьох блоків. Фактори цих блоків, за своїм походженням не пов'язані між собою. До першого блоку чинників належать фізико-хімічні властивості вугілля, що з'явилися у результаті перетворення пластів під впливом глибинних геологічних процесів в надрах Землі. У загальному випадку такі зміни відносять до метаморфічних процесів. Вони полягають у перетворенні бурого вугілля послідовно в кам'яне вугілля та антрацит в результаті зміни хімічного складу, структури і фізичних властивостей переважно під впливом підвищеної температури та тиску [9].

До факторів другого блоку належать гірничо-геологічні умови залягання вугільних пластів. Вони характеризуються потужністю пласта $(m)$, кутом його падіння $(\alpha)$, наявністю і розташуванням зближених пластів щодо розроблюваного, властивостями порід (покрівлі та підошви) та ін.

Третій блок факторів характеризує гірничотехнічні (технологічні) умови ведення гірничих робіт. До них належать способи розкриття вугільних родовищ, системи розробки, технологія ведення гірничих робіт, схеми провітрювання гірничих виробок, засоби механізації основних і допоміжних процесів, які забезпечують основні функції життєдіяльності гірничого підприємства.

Для виникнення ситуації, що сприяє прояву одного 3 небезпечних властивостей вугільного шахтопласта і створенню умов для ініціювання та протікання аварії, необхідно деяке сполучення між параметрами факторів всіх трьох блоків. Таке співвідношення формується як на стадіях метаморфічних перетворень шахтопластів під впливом факторів першого блоку, так і чинників наступних блоків. Початок логічного ланцюжка кількісних і якісних співвідношень між параметрами впливаючих факторів усіх трьох блоків формується вже на стадії проєктування вугільної шахти. Критичне поєднання значень факторів усіх трьох блоків, яке необхідне для прояву небезпечної властивості шахтопласта і виникнення

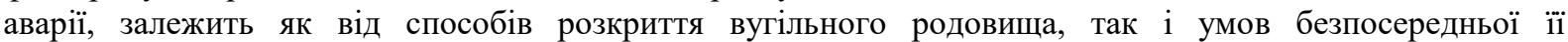
експлуатації. Вимоги нормативних документів [1-8] спрямовані на запобігання виникненню критичних співвідношень між параметрами впливаючих факторів усіх трьох блоків. Ефективність запропонованих заходів щодо запобігання або зниження ймовірності прояву небезпечної властивості вугільного шахтопласта в цьому випадку залежить як від достовірності визначення впливаючих факторів, так i значень їх параметрів. На стадіях проєктування і експлуатації вугільного підприємства можна вплинути на вибір факторів та їх значення тільки для третього блоку. Фактори першого і другого блоків сформовані геологічною історією вугільного родовища і вони є незмінною базою для вибору параметрів факторів третього блоку, що безпосередньо визначають умови ведення гірничих робіт. Від достовірності визначення факторів перших двох блоків і значень їх параметрів залежить достовірність вибору параметрів факторів третього блоку і в кінцевому підсумку точність прогнозування безпечного ведення гірничих робіт в цілому. Висока точність визначення параметрів гірничо-геологічних факторів другого блоку (потужність пласта $(m)$, його будова та кут падіння $(\alpha)$, глибина залягання $(H)$, властивості порід та ін.) попередньо встановлюється ще на стадії розвідки вугільного родовища. Потім вони уточнюються в процесі розкриття та експлуатації родовища.

Абсолютно протилежна ситуація склалася в питаннях достовірності визначення факторів першого блоку, які визначають ступінь метаморфічних перетворень вугільних шахтопластів. Виходячи 3 класичного визначення поняття «ступеня метаморфізму», можна зазначити, що при прогнозі небезпечних властивостей шахтопластів за генетичними ознаками необхідно розглядати зміни у складі та структурі вугілля, що відбулися в результаті геологічних перетворень. У всіх нормативних документах України, які передбачають безпечне відпрацювання вугільних шахтопластів, використовуються класифікаційні показники, які лише побічно, і певною мірою характеризують зміни у складі та структурі вугілля в процесі їх метаморфічних перетворень. У загальному випадку таких показників у нормативній базі прийнято обмежену їх кількість: масовий вихід летких речовин при термічному розкладанні вугілля без доступу повітря $\left(V^{\mathrm{daf}}\right)$, товщина пластичного шару $(y)$, об'ємний вихід летких речовин $\left(V_{\mathrm{v}}^{\mathrm{daf}}\right)$ та логарифм питомого електроопору антрацитів $(\lg \rho)$. Кожен 3 цих показників був розроблений для характеристики споживчих властивостей вугілля. Методики їх визначення базуються на встановленні 
абсолютно різних властивостей. Показники $V^{\mathrm{daf}}$ та $V_{\mathrm{v}}^{\mathrm{daf}}$ характеризують [10] суму газів, що виділилися $\left(\mathrm{H}_{2}, \mathrm{CH}_{2}, \mathrm{CO}, \mathrm{CO}_{2}\right)$, за якою немає безпосередньої можливості встановити зміни в елементному складі або структурі вугілля. За своєю суттю процес термічної деструкції вугілля згідно 3 методиками визначення $V^{\text {daf }}$ та $V_{\mathrm{v}}^{\text {daf }}[11,12] \epsilon$ черговою штучної стадією перетворення органічної маси в лабораторних умовах, які не відповідають метаморфічним перетворенням шахтопластів у надрах Землі. Ці невідповідності обумовлені попереднім збагаченням проб вугілля до рівня зольності менше 10 \% і їх зневодненням.

Логарифм питомого електроопору антрацитів $(\lg \rho)$ характеризує діелектричні властивості тільки антрацитів і не має відношення до складу та властивостей кам'яного вугілля.

Товщина пластичного шару (y) є продуктом сухої перегонки вугілля [13] і характеризує вихід кам’яної вугільної смоли. Цей показник розроблений для встановлення коксівності вугілля.

За методиками визначення $V^{\mathrm{daf}}, V_{\mathrm{v}}^{\mathrm{daf}}, \lg \rho$ та $y$ однозначно неможливо встановити, які небезпечні властивості шахтопластів вони характеризують, оскільки розроблені і призначені для встановлення споживчих властивостей вугілля. До теперішнього часу наукове обгрунтування застосовуваних показників ступеня метаморфізму вугілля для прогнозу небезпечних властивостей шахтопластів не проводилося. Здебільшого для цих цілей використовується показник $V^{\mathrm{daf}}$. Паралельно з ним, у тому числі і в нормативних документах, для цих цілей використовуються інші показники. До них, наприклад, належить використання марочної приналежності вугілля. Згідно ж 3 офіційно встановленим визначенням [9] марка вугілля - це умовне позначення різновидів вугілля, близьких за генетичними ознаками та основними енергетичними і технологічними характеристикам. В цьому випадку енергетичні та технологічні властивості також безпосередньо не відображають прояви будь-яких конкретних небезпечних властивостей шахтопластів. Науково обгрунтовано [14], що окремо взятий будь-який класифікаційний показник ступеня метаморфізму відображає одну 3 його сторін, притаманну лише цьому показнику. 3 огляду на нелінійні, як правило, взаємозалежності між окремими показниками (рис. 1), практично виключена можливість безпосередньої заміни одного показника іншим. Така особливість врахована в сучасній класифікації вугілля [21] при визначенні їх споживчих властивостей. За основний, реально визначений у всьому ряду ступеня метаморфізму, прийнятий показник середнього відбиття вітриніту $\left(R_{\mathrm{o}}\right)$. Показники виходу летких речовин $\left(V^{\mathrm{daf}}, V_{\mathrm{v}}^{\mathrm{daf}}\right)$ та максимальної вологоємності $\left(W_{\max }\right)$ прийняті як додаткові для уточнення особливостей споживчих властивостей вугілля.

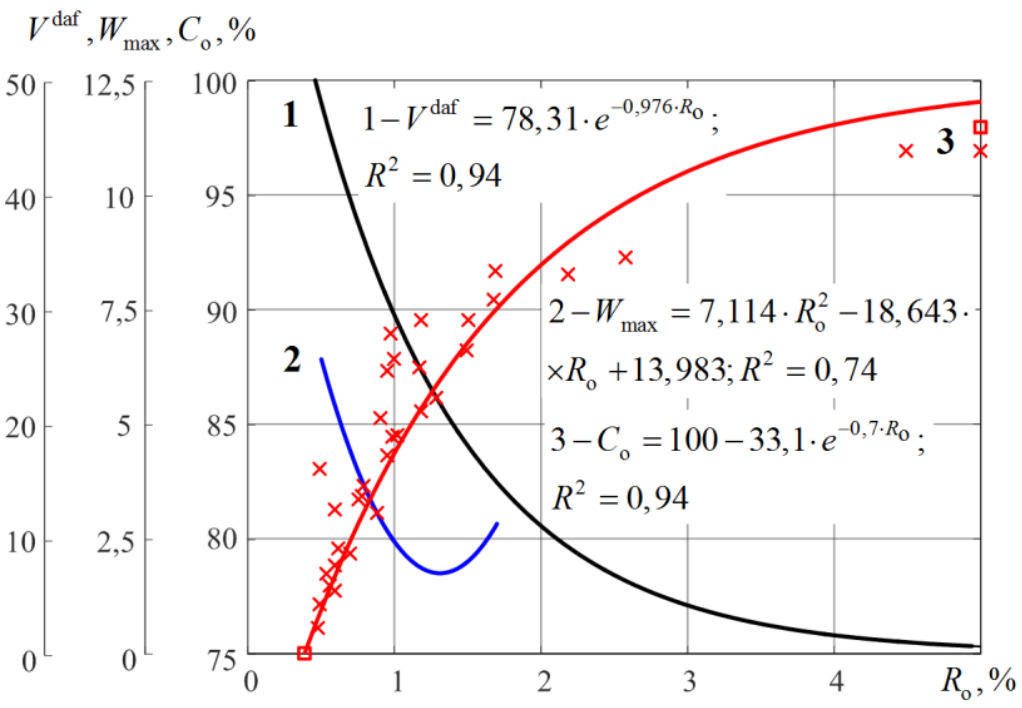

1 - крива залежності виходу летких речовин $V^{\text {daf }}[15]$;

2 - крива залежності максимальної вологоємності $W_{\max }$ [16];

3 - крива залежності вмісту вуглецю в органічній речовині $C_{\text {o. }}$.

$\times \quad$ - експериментальні дані взаємозалежності вмісту вуглецю в органічній речовині $\left(C_{0}\right)$ i показника середнього відбиття вітриніту $\left(R_{\mathrm{o}}\right)$ згідно з [17-19];

口 - точки, положення яких визначає максимальне $\left(C_{0}=98 \%\right.$, $\left.R_{\mathrm{o}}=5,0 \%\right)$ та мінімальне значення $\left(C_{0}=75 \%, R_{0}=0,4 \%\right)[20,21]$; $R^{2}$ - коефіцієнти детермінації

Рис. 1. Залежність основних класифікаційних показників ступеня метаморфізму вугілля від відбиття вітриніту $R_{\mathrm{o}}$

При розробці нормативної бази щодо безпечного ведення гірничих робіт такий принцип підбору класифікаційних показників не дотримувався. Здебільшого як основний показник ступеня метаморфізму прийнято масовий вихід летких речовин $\left(V^{\mathrm{daf}}\right)$. Достовірне його визначення ускладнене для малометаморфізованого кам'яного вугілля та антрацитів, які розташовані відповідно на початку і в кінці ряду їх ранжирування за метаморфічними ознаками.

Показник відбиття вітриніту $\left(R_{\mathrm{o}}\right)$ у всьому світі прийнятий як універсальний і надійний параметр для кількісної оцінки стадії метаморфізму вугілля. Він $€$ зовнішнім відображенням глибоких молекулярних 
перетворень органічної речовини вихідного рослинного матеріалу в умовах його накопичення і далі в процесах торфоутворення, діагенезу та метаморфізму [20]. Показник $R_{\mathrm{o}}$ корелює з вмістом вуглецю $C_{\mathrm{o}}$, виходом летких речовин та іншими параметрами складу та структури вугілля. Це дозволяє вважати його одним із найбільш об'єктивних параметрів оцінки стадії метаморфізму вугілля. Між показниками $C_{\mathrm{o}}$ i $R_{\mathrm{o}}$ спостерігається нелінійна взаємозалежність (рис. 1), що вказує на характеристику ними різних сторін метаморфічних перетворень, які відображають відповідно зміни елементного складу та структури вугілля [22]. Показники $C_{\text {o }}$ і $R_{0}$, незважаючи на їх універсальність та надійність визначення ними складу і властивостей вугілля, в нормативній базі [1-8] не використовуються для прогнозу небезпечних властивостей шахтопластів. Універсальність показників необхідна для встановлення загальних ознак прояву різних небезпечних властивостей шахтопластів. Передбачається [23] деякий взаємозв'язок між вибуховістю вугільного пилу, раптовими викидами вугілля й газу та виникненням вибухопожежонебезпечних ситуацій. Встановлено також схильність вугілля до самозаймання залежно від їх дробильності [24]. Але, не дивлячись на наявність можливого зв'язку між деякими небезпечними властивостями шахтопластів і універсальність показників $\left(R_{0}, C_{\mathrm{o}}\right)$, не можна не брати до уваги існування інших показників, які більш точно відображають одну зі сторін метаморфічного перетворення вихідного матеріалу.

Труднощі вивчення впливу окремих факторів на виникнення аварійних ситуацій полягає в неможливості, серед більшості випадків, повторного їх відтворення. Сдиним винятком з цього правила $є$ пилоутворювальна здатність шахтопластів. Ї̈ї можна оцінити при веденні гірничих робіт за результатами безпосередніх замірів до виникнення аварійної ситуації. Безумовно, пилоутворювальна здатність пов'язана 3 дробильністю вугілля, яка в свою чергу, визначає ендогенну пожежонебезпеку шахтопластів [24]. Не виключений також вплив пилоутворювальної здатності на виникнення вибухопожежонебезпечних ситуацій [23].

Попередньо проведено аналіз використовуваних показників та їх приналежність до одного з блоків впливаючих факторів. Градація всіх шахтопластів проведена [4] на вісім груп за пиловим фактором. Як основний фактор прийнято питоме пиловиділення $q$, г/т (табл. 1).

Таблиия 1

Градація вугільних шахтопластів на групи за питомим пиловиділенням (q) згідно з «Каталогом ...»

\begin{tabular}{|c|c|c|c|c|c|c|c|c|}
\hline $\begin{array}{c}\text { Діапазон зміни } \\
\text { питомого } \\
\text { пиловиділення } q, \Gamma / \mathrm{T}\end{array}$ & $\begin{array}{l}\text { менше } \\
50\end{array}$ & $50-100$ & $100-150$ & $150-250$ & $250-400$ & $400 \div 600$ & $600 \div 1000$ & $\begin{array}{l}\text { більше } \\
1000\end{array}$ \\
\hline $\begin{array}{c}\text { Група запиленості } \\
\text { шахтопластів }\end{array}$ & I & II & III & IV & V & VI & VII & VIII \\
\hline
\end{tabular}

Для кожного значення $q$ в каталозі наведено відповідні їм показники передбачуваних впливаючих факторів. Як такі прийняті вихід летких речовин ( $\left.V^{\mathrm{daf}}\right)$, потужність пластів, що розробляються $(m)$, кути їх залягання $(\alpha)$, загальна вологість вугілля $\left(W^{t}\right)$ та вміст пилу у відбитому вугіллі $(N)$. Значення кутів залягання шахтопластів враховувалися за їх відношенням до пластів пологого залягання $\left(\alpha<35^{\circ}\right)$ або до крутопадаючих $\left(\alpha>35^{\circ}\right)$. Відомості про кількість аналізованих шахтопластів за факторами $\left(V^{\mathrm{daf}}, m, W^{\mathrm{t}}\right.$, $N, q$ ) наведено в таблиці 2.

Таблиия 2

Відомості про показники та кількість аналізованих шахтопластів у різних вугільних басейнах, згідно з «Каталогом ...» [4]

\begin{tabular}{|c|c|c|c|c|c|c|c|c|c|c|c|}
\hline \multirow[b]{3}{*}{$\begin{array}{c}\text { Вугільні } \\
\text { родовища }\end{array}$} & \multirow[b]{3}{*}{$\begin{array}{c}\text { Залягання } \\
\text { пластів }\end{array}$} & \multicolumn{10}{|c|}{ Показник } \\
\hline & & \multicolumn{2}{|c|}{$V^{\text {daf }}, \%$} & \multicolumn{2}{|c|}{$m, \mathrm{M}$} & \multicolumn{2}{|c|}{$W^{t}, \%$} & \multicolumn{2}{|c|}{$N, \%$} & \multicolumn{2}{|c|}{$q, \%$} \\
\hline & & 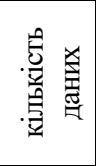 & 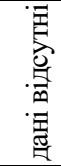 & 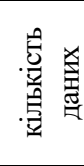 & 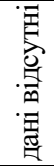 & 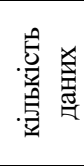 & 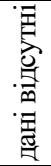 & 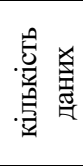 & 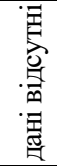 & 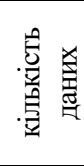 & 胥 \\
\hline \multirow{3}{*}{$\begin{array}{c}\text { Колишній } \\
\text { Радянський } \\
\text { Союз }\end{array}$} & пологе & 1346 & 26 & 1372 & 0 & 1371 & 1 & 1363 & 9 & 1364 & 8 \\
\hline & крутопадаюче & 754 & 1 & 755 & 0 & 755 & 0 & 752 & 3 & 750 & 5 \\
\hline & $\begin{array}{c}\text { пологе та } \\
\text { крутопадаюче }\end{array}$ & 2100 & 27 & 2127 & 0 & 2126 & 1 & 2115 & 12 & 2114 & 13 \\
\hline \multirow{3}{*}{$\begin{array}{c}\text { Донбас та } \\
\text { Львівсько- } \\
\text { Волинський } \\
\text { басейн }\end{array}$} & пологе & 978 & 6 & 984 & 0 & 982 & 2 & 976 & 8 & 976 & 8 \\
\hline & крутопадаюче & 745 & 0 & 745 & 0 & 745 & 0 & 742 & 3 & 740 & 5 \\
\hline & $\begin{array}{c}\text { пологе та } \\
\text { крутопадаюче }\end{array}$ & 1723 & 6 & 1729 & 0 & 1727 & 2 & 1718 & 11 & 1716 & 13 \\
\hline
\end{tabular}


У «Каталозі...» [4] наведено значення показників $\left(\alpha, V^{\mathrm{daf}}, m, W^{t}\right.$ i $\left.N\right)$, які дозволяють аналізувати їх вплив на рівень питомого пиловиділення $(q)$. Від значення $q$ в кінцевому підсумку залежить ступінь прояву одного з небезпечних властивостей шахтопластів при веденні гірничих робіт та ефективність розроблюваних заходів щодо його запобігання або скорочення шкідливого впливу.

При складанні «Каталогу...» [4] передбачався вплив факторів першого блоку $V^{\mathrm{daf}}, W^{\mathrm{t}}$ i $N$ на рівень питомого пиловиділення. Залежність $q$ від гірничо-геологічних факторів другого блоку враховувалася значеннями $\alpha$ та $m$. Фактори третього блоку, що характеризують гірничотехнічні (технологічні) умови відбою вугілля, під час складання каталогу до уваги не бралися. При прийнятому поєднанні впливаючих факторів можна припустити, що значення $V^{\text {daf }}$ характеризує загальний ступінь метаморфічних перетворень органічної маси, $W^{t}$ - в деякій частині глибину здійснених метаморфічних процесів і фізикохімічний стан вугілля, $\alpha$ та $m$ - гірничо-геологічні умови залягання шахтопластів. У цьому переліку відсутні фактори третього блоку, які характеризують технологію і засоби механізації. Очевидно, що без оцінки виїмкових машин за пиловим фактором неможливо робити градацію шахтопластів на групи їх запиленості. Це підтверджується методикою визначення $q$, яка вказана в «Руководстве...» [4] паралельно 3 «Каталогом...». Значення $q$ рекомендується приймати для конкретних шахтопластів згідно 3 каталогом (додаток 4) або розраховувати за залежністю:

$$
q=150 \cdot N \cdot k_{\mathrm{B}} \cdot k_{\mathrm{m}} \cdot k_{\mathrm{T}}, \Gamma / \mathrm{T},
$$

де $N$ - вміст в зруйнованому вугіллі частинок, розміром менше за 70 мкм при еталонному режимі руйнування, \%;

$k_{\text {в }}$ коефіцієнт, що враховує середньозважене значення вологості вугілля. Приймається для різних вугільних басейнів при $W^{t}=0,75 \div 14 \%$ в діапазоні $1,8 \div 0,09$;

$k_{\mathrm{m}}$ - коефіцієнт, що враховує середньозважене значення виймальної потужності пласта. При $m=0,5 \div$ 3,5 м значення $k_{\mathrm{m}}$ рекомендується приймати в інтервалі $0,5 \div 2,3$;

$k_{\mathrm{T}}$ - коефіцієнт, що враховує вплив температури пласта тільки в умовах вугільних родовищ, розташованих у зоні багаторічномерзлих порід.

Вміст у зруйнованому вугіллі частинок, розміром менше за 70 мкм розраховується за формулою:

$$
N=100\left[1-\exp \left(-\lambda \cdot 0,07^{i}\right)\right], \%,
$$

де $\lambda$ - показник ступеня подрібнення вугілля, який визначається для еталонного режиму;

$i$ - показник здатності вугілля до подрібнення. Визначається за даними ситового аналізу експлуатаційних проб вугілля, зруйнованого конкретною вугледобувною машиною.

Значення $\lambda$ встановлюється залежно від $i$, а вміст пилу в зруйнованому вугіллі $N$ розраховується за рівнянням 2. Використовуючи значення $N$ за рівнянням 1 , розраховується значення $q$ і відповідно до градації (табл. 1) шахтопласт належить до однієї з груп за питомим пиловиділенням і вибираються рекомендовані заходи по боротьбі з пилом.

Для розрахунку відповідно до рівняння (1) питомого пиловиділення $(q)$ використовуються фактори всіх трьох блоків. Їх сполучення істотно відрізняється від наведених у «Каталозі...». 3 факторів першого блоку до розрахунку приймається тільки вологість $\left(W^{t}\right)$, а з другого - потужність пласта $(m)$. Фактори третього блоку характеризують тип комбайна, його продуктивність та усереднений сумарний вихід класів крупності відбитого вугілля. 3 зіставлення експериментальних значень факторів, наведених у «Каталозі...» і використовуваних для розрахунку пилоутворювальної здатності вугільних пластів, виходить, що вони характеризують різні сторони процесу пилоутворення.

У «Каталозі...» питоме пиловиділення зіставляється з трьома показниками ступеня метаморфізму $\left(V^{\mathrm{daf}}, W^{\mathrm{t}}\right.$ та $\left.N\right)$, що відображають різні сторони процесів геологічного перетворення.

У розрахунках $q$ відповідно до рівняння (1) з метаморфічних показників використовується тільки вологість $\left(W^{t}\right) .3$ гірничо-геологічних факторів другого блоку застосовується потужність пласта $(m)$, а кут його залягання $(\alpha)$ не береться до уваги. Поряд з цим враховується тип комбайна, його продуктивність та усереднений сумарний вихід класів відбитого вугілля.

3 наведених фактів випливає, що значення питомого пиловиділення в «Каталозі ...» [4] характеризуються трьома показниками ступеня метаморфізму, а фактори третього блоку, що визначають технологію відбою вугілля, взагалі не розглядаються.

При визначенні ж розрахункової пилоутворювальної здатності вугільного пласта відповідно до рівняння (2) основна увага приділена факторам третього блоку (тип виїмкових машин, їх продуктивність, усереднений сумарний вихід класів відбитого вугілля). 3 факторів першого блоку враховується тільки вологість. Використання одного цього показника виявилося недостатнім для розв'язання задачі оцінки виймальних комбайнів за пиловим фактором. Для цих цілей додатково залучені опірність вугілля різанню та характеристики марок вугілля за крихко-пластичними властивостями.

Таким чином, в одному нормативному документі [4] для характеристики метаморфічних перетворень шахтопластів застосовано шість класифікаційних показників, що відображають різні сторони процесів. Ця обставина й нелінійні взаємозалежності між факторами першого блоку привели до певних 
суперечностей в оцінці пилоутворювальної здатності вугілля в ряду їх метаморфізму [25]. 3 одного боку, зроблено висновок, що на запиленість повітря на 85 \% впливає марка вугілля (на думку авторів, вона характеризує метаморфізм), але 3 нею тісно пов'язані вологість та характеристики міцності. 3 іншого боку, трьохфакторний дисперсійний аналіз при угрупованні марка вугілля - опірність різанню вологість показав, що вплив марки на запиленість повітря несуттєвий. Авторами [25] зроблено висновок про те, що відмінності запиленості повітря та пилоутворювальної здатності в ряду метаморфізму вугілля визначаються їх міцністю й вологістю. На підставі ж обробки даних «Каталогу...» [4] ними запропоновано рівняння для розрахунку $q$ залежно тільки від $V^{\text {daf }}$ та $W^{t}$ без урахування міцності вугілля i ділення шахтопластів по кутах їх залягання.

Наведений аналіз впливу на пилоутворювальну здатність шахтопластів факторів трьох блоків згідно 3 даними «Руководства...» [4] показує, що достовірно не встановлена роль кожного фактора у формуванні питомого пиловиділення та градації шахтопластів на групи по їх запиленості.

Експериментальні дані «Каталогу...» [4] дозволяють розрахувати статистичні моделі рядів розподілу за показниками $V^{\mathrm{daf}}, q, W^{t}$ та $N$, які належать до першого блоку і кожен з них характеризує одну зі сторін метаморфічних перетворень шахтопластів.

Дані «Каталогу...» [4] дозволяють також розглянути статистичні моделі розподілу шахтопластів по їх потужності $(m)$, яка належить до другого блоку. Така можливість аналізу статистичних моделей виключена за фактором зміни кута залягання шахтопластів $(\alpha)$ через наявність лише двох характерних сукупностей. Одна 3 низ відповідає $\alpha<35^{\circ}$, а друга - значенням $\alpha>35^{\circ}$. Для встановлення можливого впливу фактора кута залягання пластів, статистичні моделі за іншими факторами ( $V^{\text {daf }}, W^{t}, N, q$, i $m$ ) розглядали шляхом порівняння їх статистичних моделей для пологого та крутопадаючого залягання шахтопластів. Для виявлення можливих відмінностей між вугільними родовищами різних басейнів окремо розглянули статистичні моделі сукупностей по зазначеним факторам для всіх шахтопластів, наведених в «Каталозі ...» [4], і шахтопластів Донбасу та Львівсько-Волинського басейну.

По фактору $V^{\text {daf }}$ у діапазоні його зміни практично від 0 до $45 \%$ характер гістограм сумарного розподілу шахтопластів пологого та крутопадаючого залягання для всіх вугільних родовищ та Донбасу спільно 3 Львівсько-Волинським басейном змінюються приблизно однаково (рис. 2, гістограма 1). Відмінності розподілу шахтопластів по фактору $V^{\mathrm{daf}}$ спостерігаються при його значеннях від 5 до $45 \%$. В Україні практично відсутні шахтопласти $3 V^{\text {daf }}>45 \%$ (всього 2), а в інших родовищах їх 95. У інтервалі зміни $V^{\text {daf }}$ від 0 до 5 \% перебувають тільки шахтопласти Донецького басейну (226). Це вказує на те, що вугілля Донбасу та Львівсько-Волинського басейну за фактором $V^{\text {daf }}$ більшою мірою, порівняно з іншими родовищами піддавалися метаморфічним перетворенням.
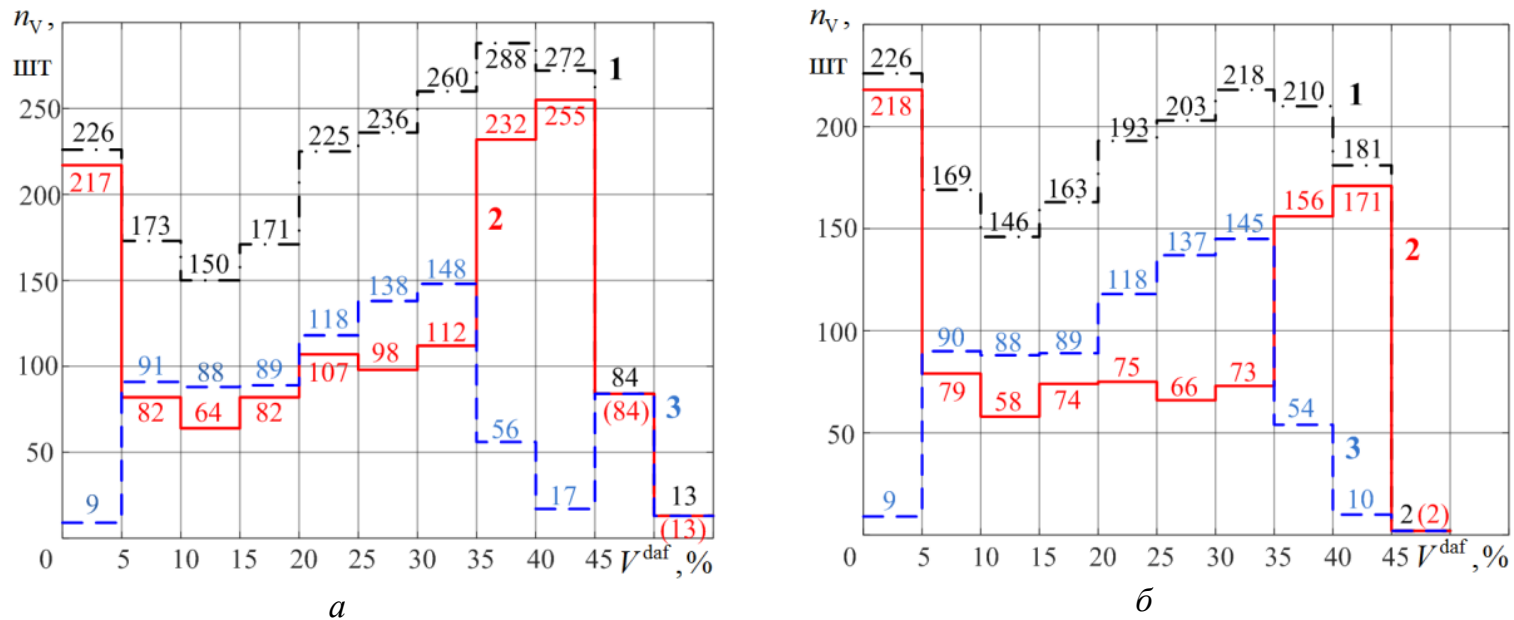

Рис. 2. Гістограми розподілу шахтопластів всіх вугільних родовищ (а) та Донбасу спільно з ЛьвівськоВолинським басейном (б) за показником виходу летких речовин ( $\left.V^{\mathrm{daf}}\right)$ згідно з «Каталогом...» [4]

$(\mathbf{1}$ - гістограми сумарного розподілу шахтопластів пологого та крутопадаючого залягання;

2, 3 - гістограми розподілу шахтопластів відповідно пологого та крутопадаючого залягання; $\underline{226}$ - кількість шахтопластів ( $\left.n_{\mathrm{V}}\right)$ в окремому інтервалі зміни $\left.V^{\mathrm{daf}}\right)$.

Гістограми 2 і 3 (рис. 2) та дані (табл. 3) дозволили встановити відмінності у сукупностях шахтопластів пологого та крутопадаючого залягання. Переважна кількість шахтопластів 2173226 високого ступеня метаморфізму перетворень $\left(V^{\text {daf }}<5 \%\right)$ належала до пластів пологого залягання. Усі крутопадаючі пласти містили вугілля 3 показником $V^{\text {daf }}<45 \%$ і основна їх кількість (745 3755$)$ припадала на крутопадаючі пласти Донбасу. Кількість пологих пластів переважає в інтервалах зміни $V^{\mathrm{daf}}$ 
$0 \div 5 \%$ і більше $35 \%$, а основна кількість крутопадаючих знаходилося в діапазоні $5 \div 35$ \%. Більшість шахтопластів крутопадаючого залягання (745) знаходилася в Донбасі (98,7 \%). У цьому ж басейні були також всі шахтопласти (226) пологого та крутопадаючого залягання 3 максимальним ступенем метаморфічних перетворень $V^{\mathrm{daf}}<5 \%$ (рис. 2). 3 цієї причини, щоб не вносити додаткові похибки при встановленні впливу ступеня метаморфізму, має сенс порівнювати шахтопласти пологого та крутопадаючого залягання тільки для родовищ Донбасу. Статистичні моделі розподілу шахтопластів пологого і крутопадаючого залягання за показником $V^{\text {daf }}$ у групах запиленості (з I по VIII) наведені в таблиці 4 .

Сукупності шахтопластів пологого та крутопадаючого залягання Донбасу та Львівсько-Волинського басейну характеризуються однаковим середнім значенням виходу летких речовин ( $\bar{V}^{\mathrm{daf}}=23,1 \%$ табл. 3 ). У групах з I по III значення $\bar{V}^{\text {daf }}$ для шахтопластів пологого залягання $(29,8 \div 32,7 \%)$ перевищують ці показники для крутопадаючих пластів $(21,6 \div 24,6$ \%). В інших групах з IV по VIII - навпаки, значення $\bar{V}^{\text {daf }}$ у групах крутопадаючих пластів $(17,9 \div 25,4 \%)$ перевищують їх значення для пологих пластів $(12,5 \div 22,2 \%)$.

Для шахтопластів пологого залягання в міру збільшення груп за пиловим фактором з I до VIII спостерігається деяка тенденція зниження $\bar{V}^{\text {daf }}$ з 32,7 до 12,5\%. Це вказує на посилення метаморфічних перетворень по фактору $V^{\text {daf }}$ зі збільшенням групи запиленості. Така тенденція зміни $\bar{V}^{\text {daf }}$ відсутня для крутопадаючих пластів. Для I групи $\bar{V}^{\mathrm{daf}}=21,6 \%$, а для VIII 23,1 \% (табл. 4). Це свідчить про те, що середнє значення неоднозначно характеризує групи запиленості шахтопластів пологого та крутопадаючого залягання.

Табличя 3

Показники статистичних моделей розподілу варіанта виходу летких речовин (V $\left.\mathrm{V}^{\mathrm{daf}}\right)$ при групуванні шахтопластів за пиловим фактором згідно з «Каталогом ...» [4]

\begin{tabular}{|c|c|c|c|c|c|c|c|c|c|c|c|c|c|c|}
\hline \multirow[b]{2}{*}{ 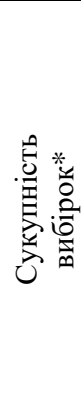 } & \multirow[b]{2}{*}{ 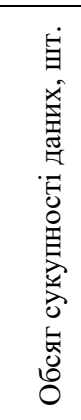 } & \multicolumn{3}{|c|}{$\begin{array}{c}\text { Значення } V^{\text {daf }} \text { у } \\
\text { вибірках, \% }\end{array}$} & \multicolumn{8}{|c|}{$\begin{array}{c}\text { Показник математичної статистики } \\
\text { рядів розподілу }\end{array}$} & \multicolumn{2}{|c|}{$\begin{array}{c}\text { Критерій } \\
\text { Пірсона }\end{array}$} \\
\hline & & 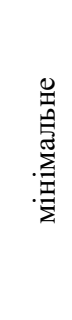 & 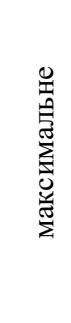 & 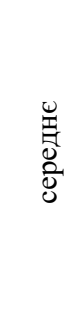 & $\underset{\frac{\pi}{5}}{\frac{\pi}{2}}$ & 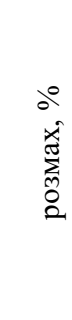 & 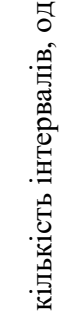 & $\begin{array}{l}\frac{\pi}{0} \\
\frac{0}{2} \\
0 \\
0 \\
0\end{array}$ & 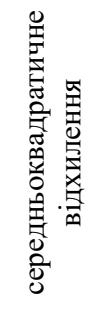 & 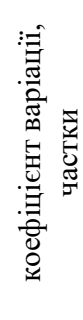 & 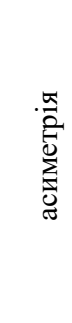 & 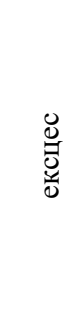 & 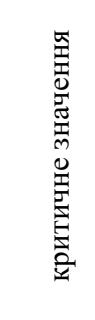 & 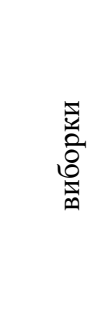 \\
\hline$*$ & $n_{\mathrm{V}}$ & $V_{\mathrm{min}}^{\mathrm{daf}}$ & $V_{\text {max }}^{\mathrm{daf}}$ & $\bar{V}^{\text {daf }}$ & $M_{\mathrm{V}}$ & $R_{\mathrm{V}}$ & $k^{\mathrm{V}}$ & $D_{\mathrm{V}}$ & $\sigma_{\mathrm{V}}$ & $k_{\text {в }}$ & $A_{\mathrm{S}}$ & $E_{\mathrm{K}}$ & $\chi_{\mathrm{\kappa p}}^{2}$ & $\chi_{\mathrm{B}}^{2}$ \\
\hline 1 & 2100 & 1,3 & 54,0 & 25,8 & 37,5 & 52,7 & 11 & 185,0 & 13,60 & 0,53 & $-0,21$ & $-1,12$ & 15,507 & 587,269 \\
\hline 2 & 1346 & 1,3 & 54,0 & 27,2 & 42,5 & 52,7 & 11 & 231,6 & 15,22 & 0,56 & $-0,37$ & $-1,27$ & 15,507 & 1021,23 \\
\hline 3 & 754 & 2,3 & 43,4 & 23,3 & 32,5 & 41,1 & 9 & 92,2 & 9,60 & 0,41 & $-0,19$ & $-0,98$ & 12,592 & 13,328 \\
\hline 4 & 1723 & 1,3 & 49,0 & 23,1 & 2,5 & 47,7 & 10 & 166,9 & 12,91 & 0,56 & $-0,12$ & $-1,26$ & 14,067 & 570,303 \\
\hline 5 & 978 & 1,3 & 49,0 & 23,1 & 2,5 & 47,7 & 10 & 223,5 & 15,02 & 0,65 & $-0,10$ & $-1,57$ & 14,067 & 982,319 \\
\hline 6 & 745 & 2,3 & 43,4 & 23,1 & 32,5 & 41,1 & 9 & 90,14 & 9,49 & 0,41 & $-0,20$ & $-0,99$ & 14,067 & 124,117 \\
\hline
\end{tabular}

Примітка: крок всіх інтервалів $\mathrm{h}_{\mathrm{v}}=5 \%$.

*1 - генеральна вибірка всіх шахтопластів пологого та крутопадаючого залягання;

2 - генеральна вибірка шахтопластів пологого залягання;

3 - генеральна вибірка пластів крутопадаючого залягання;

4 - вибірка шахтопластів пологого та крутопадаючого залягання Донбасу і Львівсько-Волинського басейну;

5 - вибірка шахтопластів пологого залягання Донбасу і Львівсько-Волинського басейну;

6 - вибірка крутопадаючих пластів Донбасу

У всіх групах $(\mathrm{I} \div \mathrm{VIII})$ розмах $R_{\mathrm{V}}$ значень $V^{\text {daf }}$ (табл. 4) для шахтопластів пологого залягання $\left(R_{\mathrm{V}}=40,2 \div 46,2\right)$ перевищує цей показник для крутопадаючих шахтопластів $\left(R_{\mathrm{V}}=12,7 \div 40,5\right)$. Мінімальне середнє значення $\bar{V}_{\min }^{\text {daf }}$ для груп шахтопластів пологого залягання $(2,6 \%)$ менше за $\bar{V}_{\min }^{\text {daf }}$ для крутопадаючих пластів $(6,6 \%)$, а середнє значення максимальних показників $\bar{V}_{\max }^{\text {daf }}$ в групах шахтопластів пологого залягання (44,5 \%) перевищує $\bar{V}_{\max }^{\text {daf }}$ для крутопадаючих пластів $(39,5 \%)$. 
Це вказує на представництво шахтопластів пологого залягання в більш широкому діапазоні зміни фактора $V^{\text {daf }}$.

Групи запиленості пологих і крутопадаючих шахтопластів відрізняються між собою і по модам їх розподілу $\left(M_{\mathrm{V}}\right)$ у відповідних групах (табл. 4). Групи шахтопластів пологого залягання (I-III), які найменш схильні до пилоутворювальної здатності, характеризуються однаковою модою $\left(M_{\mathrm{V}}=42,5 \%\right)$. Решта груп шахтопластів пологого залягання з IV по VIII включно також характеризуються одним значенням моди $\left(M_{\mathrm{V}}=2,5\right.$ \%). Наведені факти вказують на переважну більшість шахтопластів пологого залягання в перших трьох групах з вмістом летких речовин близько 42,5 \%, що характерно для кам'яного вугілля незначного ступеня метаморфічних перетворень. Решта груп (IV-VIII) представлені відповідно до класифікації [21] більшою мірою антрацитовими пластами, оскільки $M_{\mathrm{V}}=2,5 \%<8 \%$.

Таблиия 4

Статистичні моделі розподілу шахтопластів Донбасу і Львівсько-Волинського басейну по виходу летких речовин $\left(V^{\mathrm{daf}}\right)$ при визначенні груп пилоутворювальної здатності згідно з «Каталогом...» [4]

\begin{tabular}{|c|c|c|c|c|c|c|c|c|c|c|c|}
\hline \multirow[b]{2}{*}{$\begin{array}{l}\text { 志 } \\
\text { 总 } \\
\text { 呪 }\end{array}$} & \multirow[b]{2}{*}{ 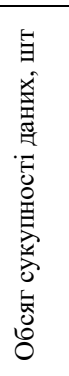 } & \multicolumn{3}{|c|}{$\begin{array}{c}\text { Значення } V^{\text {daf }} \text { у вибірках, } \\
\%\end{array}$} & \multicolumn{7}{|c|}{$\begin{array}{l}\text { Показник математичної статистики } \\
\text { рядів розподілу }\end{array}$} \\
\hline & & 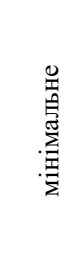 & 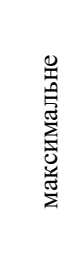 & 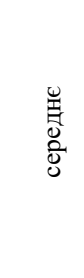 & 孪 & 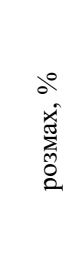 & 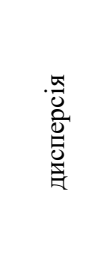 & 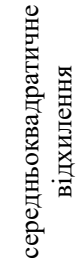 & 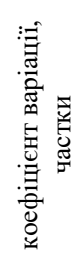 & 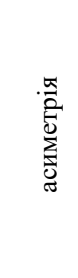 & $\begin{array}{l}\mathscr{U} \\
\tilde{U} \\
\stackrel{y}{0}\end{array}$ \\
\hline & $n_{\mathrm{V}}$ & $V_{\mathrm{min}}^{\mathrm{daf}}$ & $V_{\max }^{\mathrm{daf}}$ & $\bar{V}^{\text {daf }}$ & $M_{\mathrm{V}}$ & $R_{\mathrm{V}}$ & $D_{\mathrm{V}}$ & $\sigma_{\mathrm{V}}$ & $k_{\mathrm{B}}$ & $A_{\mathrm{S}}$ & $E_{\mathrm{K}}$ \\
\hline \multicolumn{12}{|c|}{ Пласти полого залягання } \\
\hline $\mathrm{I}$ & 100 & 2,8 & 49,0 & 21,7 & 42,5 & 46,2 & 155,9 & 12,49 & 0,38 & $-1,20$ & 0,08 \\
\hline II & 204 & 2,0 & 45,5 & 29,8 & 42,5 & 43,5 & 176,7 & 13,29 & 0,45 & $-0,78$ & $-0,89$ \\
\hline III & 143 & 2,1 & 44,5 & 30,5 & 42,5 & 42,4 & 166,2 & 12,89 & 0,42 & $-0,97$ & $-0,34$ \\
\hline IV & 143 & 1,3 & 44,5 & 22,2 & 2,5 & 43,2 & 195,8 & 13,99 & 0,63 & $-0,04$ & $-1,42$ \\
\hline $\mathrm{V}$ & 168 & 2,0 & 43,3 & 16,5 & 2,5 & 41,3 & 193,6 & 13,91 & 0,84 & 0,50 & $-1,31$ \\
\hline VI & 97 & 1,6 & 41,8 & 13,6 & 2,5 & 40,2 & 149,1 & 12,21 & 0,90 & 0,86 & $-0,64$ \\
\hline VII & 65 & 1,6 & 44,5 & 12,5 & 2,5 & 42,9 & 127,6 & 11,30 & 0,91 & 1,00 & $-0,05$ \\
\hline VIII & 51 & 2,3 & 43,0 & 12,5 & 2,5 & 41,0 & 113,0 & 10,63 & 0,85 & 1,18 & 0,66 \\
\hline \multicolumn{12}{|c|}{ Пласти крутопадаючого залягання } \\
\hline I & 37 & 8,1 & 43,4 & 21,6 & 17,5 & 35,3 & 91,3 & 9,55 & 0,44 & 0,38 & $-0,68$ \\
\hline II & 221 & 5,2 & 40,0 & 22,1 & 27,5 & 34,8 & 92,9 & 9,64 & 0,44 & $-0,09$ & $-1,25$ \\
\hline III & 123 & 2,9 & 43,4 & 24,6 & 22,5 & 40,5 & 77,0 & 8,77 & 0,36 & $-0,36$ & $-0,47$ \\
\hline IV & 109 & 7,6 & 38,0 & 24,6 & 27,5 & 30,4 & 71,9 & 8,48 & 0,35 & $-0,51$ & $-0,95$ \\
\hline $\mathrm{V}$ & 37 & 7,1 & 40,7 & 25,4 & 32,5 & 33,6 & 83,2 & 9,12 & 0,36 & $-0,36$ & $-0,66$ \\
\hline VI & 9 & 2,7 & 40,2 & 17,93 & - & 37,5 & 156,5 & 12,51 & 0,70 & 0,72 & $-0,60$ \\
\hline VII & 4 & 2,3 & 41,2 & 24,2 & - & 38,9 & 278,8 & 16,70 & 0,69 & $-0,73$ & 0,08 \\
\hline VIII & 3 & 17,0 & 29,7 & 23,1 & - & 12,7 & 40,5 & 6,36 & 0,27 & 0,31 & - \\
\hline $\mathrm{IX}^{*}$ & 197 & 3,4 & 43,3 & 22,2 & 32,5 & 39,9 & 96,17 & 9,81 & 0,44 & $-0,14$ & 1,01 \\
\hline $\mathrm{X}^{* *}$ & 5 & 9,0 & 42,4 & 28,6 & - & 33,4 & 159,3 & 12,62 & 0,44 & $-0,93$ & 1,15 \\
\hline
\end{tabular}

Примітка: *-сукупність шахтопластів, для якої конкретно не визначена група за пиловим фактором;

** - шахтопласти, для яких не зазначена група за пиловим фактором

Зовсім по-іншому розподілені шахтопласти крутопадаючого падіння за показником $M_{\mathrm{v}}$. Для перших трьох груп він значно нижчий порівняно 3 першими трьома групами пологого залягання. При $M_{\mathrm{V}}=17,5 \div 27,5 \%$ основна кількість крутопадаючих шахтопластів перших трьох груп містить кам'яне вугілля середнього ступеня метаморфізму за показником $V^{\text {daf }}$. Вугілля IV та V груп шахтопластів крутопадаючого залягання менш метаморфізовані $M_{\mathrm{V}}=27,5 \div 32,5 \%$ порівняно з попередніми групами, але вони належать, попри це, до більш високої групи за пиловим чинником. Повне протиріччя за показником $M_{\mathrm{V}}$ спостерігається між IV i V групами крутопадаючого падіння 3 цими групами пологого залягання. Пологі пласти цих груп представлені, в основному, антрацитами $\left(M_{\mathrm{V}}=2,5 \%\right)$, а крутопадаючі - кам’яним вугіллям середнього ступеня метаморфізму $\left(M_{\mathrm{V}}=27,5 \div 32,5 \%\right)$.

Крутопадаючі пласти VI-VIII груп представлені малою їх кількістю (табл. 4), що не дає можливості судити про моду в цих групах. Крім цього, для 197 шахтопластів крутопадаючого залягання не вказані 
конкретні групи за пиловим фактором і вони сформовані в окрему сукупність. С також п’ять крутопадаючих шахтопластів, для яких взагалі не вказана група за пиловим фактором.

Більш повне уявлення про відмінності між групами шахтопластів пологого і крутопадаючого залягання за пиловим фактором дають дані про крайні значення параметрів статистичних моделей виходу летких речовин (табл. 5). У жодному разі при розгляді крайніх значень параметрів $\bar{V}_{\min }^{\mathrm{daf}}, \bar{V}_{\max }^{\mathrm{daf}}$, $\bar{V}^{\mathrm{daf}}, R_{\mathrm{V}}$ та $M_{\mathrm{V}}$ групи по запиленості шахтопластів пологого і крутопадаючого залягання не збіглися. У двох випадках крайні значення $\bar{V}_{\min }^{\text {daf }}$ i $R_{\mathrm{V}}$ шахтопластів пологого та крутопадаючого залягання характеризували протилежні групи запиленості. Так за фактором $\bar{V}_{\mathrm{min}}^{\mathrm{daf}}$ при його максимальному крайньому значенні (2,8 \%) пласти пологого падіння належали до групи I (табл. 5), крутопадаючі, при значенні цього ж показника 17,0 \% - до групи VIII. За фактором MV при його мінімальному крайньому значенні (2,5 \%) пологі шахтопласти зараховані до групи VIII, а крутопадаючі при значенні цього показника 17,5 \% - до групи I. При такій градації пилоутворювальної здатності шахтопластів за фактором $V^{\text {daf }}$ відсутня однозначність визначення груп за пиловим фактором, тобто показник $V^{\text {daf }}$ навіть орієнтовно не характеризує групи запиленості шахтопластів. Через це немає підстав його використовувати для встановлення пилоутворювальної здатності шахтопластів як показник метаморфічних перетворень викопного вугілля.

Таблиия 5

Крайні значення параметрів статистичних моделей виходу летких речовин ( $\left.V^{\mathrm{daf}}\right)$ в сукупності їх груп за пилоутворювальною здатністю шахтопластів Донбасу та Львівсько-Волинського басейну згідно з «Каталогом...» [4]

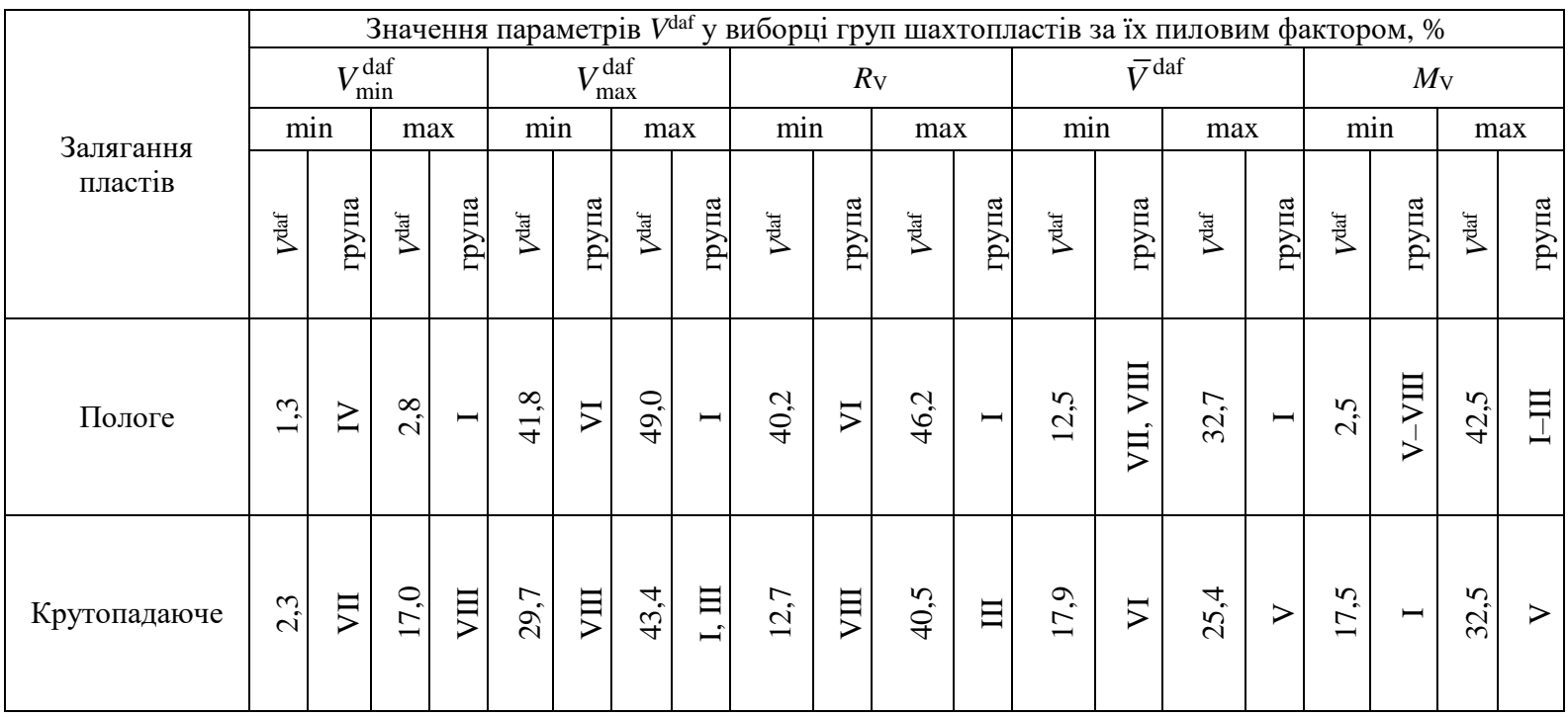

За фактором потужності $(m)$ характер гістограм сумарного розподілу шахтопластів пологого та крутопадаючого залягання для всіх вугільних родовищ (рис. 3, a, гістограма 1) та Донбасу спільно 3 Львівсько-Волинським басейном (рис. 3, 6 , гістограма 1) змінюються приблизно однаково.

Гістограми 2 і 3 (рис. 3 і табл. 6) дозволили встановити схожість у сукупностях шахтопластів пологого та крутопадаючого залягання по їх потужності. Більшість шахтопластів крутопадаючого залягання (745), як і за фактором $V^{\text {daf }}$, знаходилася в Донбасі $(98,7$ \%). 3 цієї причини порівняння сукупностей шахтопластів пологого та крутопадаючого залягання в групах за схильністю до пилоутворення розглянули для Донбасу та Львівсько-Волинського басейну (табл. 7). 

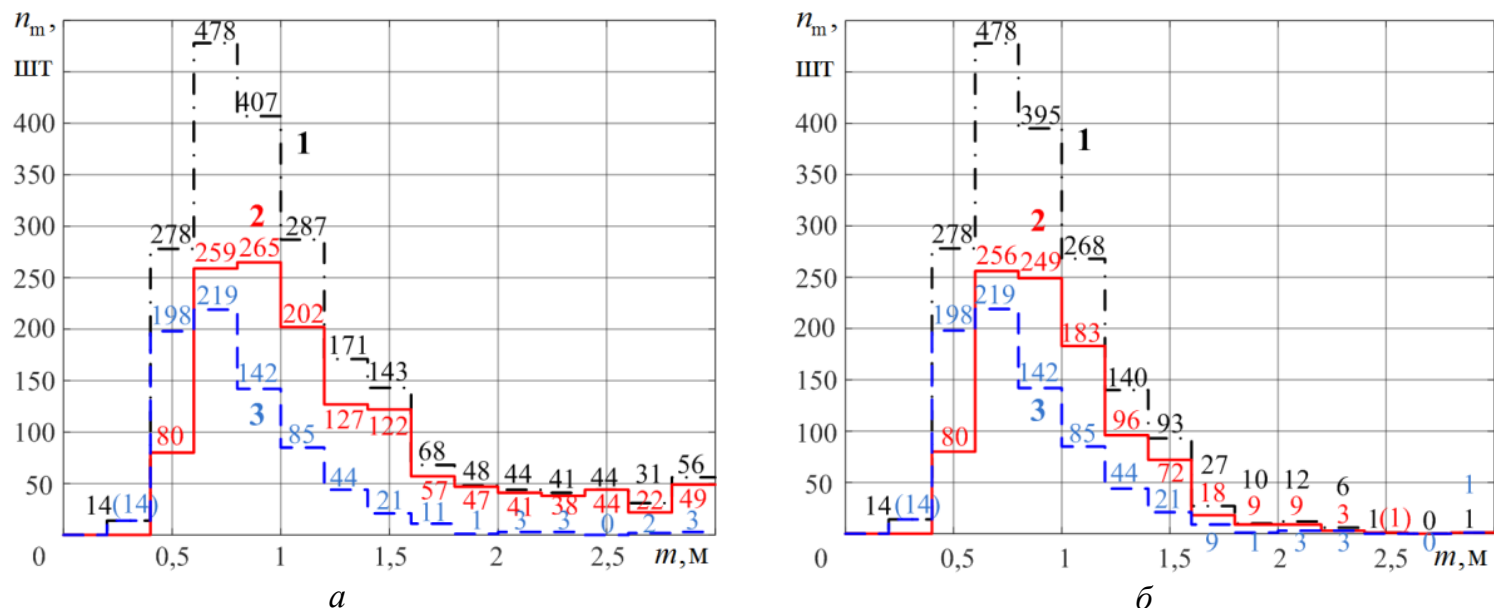

Рис. 3. Гістограми розподілу шахтопластів усіх вугільних родовиш (а) та Донбасу спільно з ЛьвівськоВолинським басейном (б) за показником потужності пластів (m) згідно з «Каталогом...» [4] (1 - гістограми сумарного розподілу шахтопластів пологого та крутопадаючого залягання; 2, 3 - гістограми розподілу шахтопластів відповідно пологого та крутопадаючого залягання; $\underline{14}$ - кількість шахтопластів $\left(n_{m}\right)$ в окремому інтервалі зміни $\left.(m)\right)$

Сукупності шахтопластів пологого і крутопадаючого залягання Донбасу та Львівсько-Волинського басейну характеризуються близькими середніми значеннями потужності пластів (відповідно $\bar{m}=0,99$ i 0,82 м, табл. 6). Не встановлено також істотних відмінностей за іншими показниками статистичних моделей розподілу за фактором $m$. Це видно 3 порівняння крайніх значень статистичних моделей потужності пластів у сукупностях їх груп по пилоутворювальній здатності (табл. 8). Це свідчить про те, що вплив показника $m$ на пилоутворювальну здатність шахтопластів при складанні «Каталогу...» [4] істотно завищений. Близькість статистичних моделей розподілу шахтопластів пологого та крутопадаючого залягання за фактором потужності пластів, що розробляються, вказує на можливість їх розгляду в одній статистичній сукупності.

Таблиия 6

Показники статистичних моделей розподілу варіант потужності пластів (m) при групуванні шахтопластів за пиловим фактором згідно з «Каталогом...» [4]

\begin{tabular}{|c|c|c|c|c|c|c|c|c|c|c|c|c|c|c|}
\hline \multirow[b]{2}{*}{ 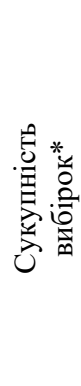 } & \multirow[b]{2}{*}{ 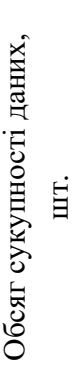 } & \multicolumn{3}{|c|}{$\begin{array}{l}\text { Значення } m \text { у } \\
\text { вибірках, \% }\end{array}$} & \multicolumn{8}{|c|}{$\begin{array}{c}\text { Показник математичної статистики } \\
\text { рядів розподілу }\end{array}$} & \multicolumn{2}{|c|}{$\begin{array}{l}\text { Критерій } \\
\text { Пірсона }\end{array}$} \\
\hline & & 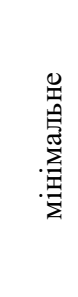 & 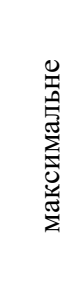 & 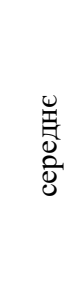 & $\begin{array}{l}\frac{\pi}{4} \\
\stackrel{2}{2}\end{array}$ & 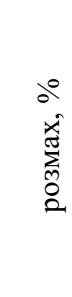 & 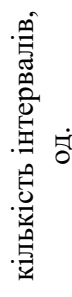 & $\begin{array}{l}\frac{\pi}{0} \\
0 \\
0 \\
0 \\
0 \\
0 \\
0\end{array}$ & 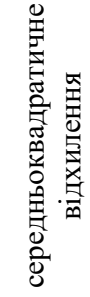 & 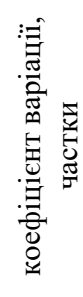 & 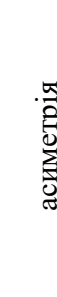 & 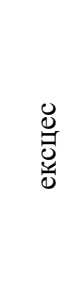 & 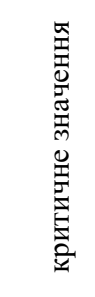 & 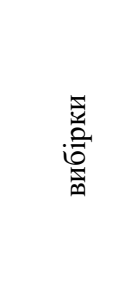 \\
\hline$*$ & $n_{\mathrm{m}}$ & $m_{\min }$ & $m_{\max }$ & $\bar{m}$ & $M_{\mathrm{m}}$ & $R_{\mathrm{m}}$ & $k^{\mathrm{m}}$ & $D_{\mathrm{m}}$ & $\sigma_{\mathrm{m}}$ & $k_{\mathrm{B}}$ & $A_{\mathrm{S}}$ & $E_{\mathrm{K}}$ & $\chi_{\text {кр }}^{2}$ & $\chi_{\mathrm{B}}^{2}$ \\
\hline 1 & 2127 & 0,31 & 5,83 & 1,14 & 0,70 & 5,52 & 30 & 0,42 & 0,646 & 0,57 & 1,96 & 5,62 & 16,919 & $1,5 \times 10^{3}$ \\
\hline 2 & 1372 & 0,31 & 5,83 & 1,30 & 0,90 & 5,52 & 30 & 0,47 & 0,683 & 0,52 & 1,58 & 3,39 & 16,919 & $1,5 \times 10^{7}$ \\
\hline 3 & 755 & 0,35 & 5,83 & 0,85 & 0,70 & 5,48 & 30 & 0,19 & 0,439 & 0,52 & 4,1 & 31,6 & 16,919 & $3,5 \times 10^{21}$ \\
\hline 4 & 1729 & 0,31 & 4,50 & 0,92 & 0,70 & 4,19 & 23 & 0,12 & 0,346 & 0,37 & 1,3 & 4,43 & 23,685 & $6,7 \times 10^{13}$ \\
\hline 5 & 984 & 0,31 & 3,00 & 0,99 & 0,70 & 2,69 & 15 & 0,11 & 0,332 & 0,33 & 1,0 & 1,51 & 21,026 & 516,54 \\
\hline 6 & 745 & 0,35 & 4,50 & 0,82 & 0,70 & 4,15 & 23 & 0,11 & 0,332 & 0,41 & 2,1 & 10,9 & 31,410 & $4,4 \times 10^{16}$ \\
\hline
\end{tabular}


Статистичні моделі розподілу шахтопластів Донбасу і Львівсько-Волинського басейну за їх потужністю (m) при визначенні груп пилоутворювальної здатності згідно з «Каталогом...» [4]

\begin{tabular}{|c|c|c|c|c|c|c|c|c|c|c|c|}
\hline \multirow[b]{2}{*}{ 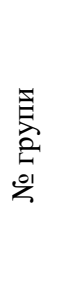 } & \multirow{2}{*}{ 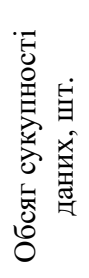 } & \multicolumn{3}{|c|}{$\begin{array}{c}\text { Значення } m \text { у вибірках, } \\
\%\end{array}$} & \multicolumn{7}{|c|}{$\begin{array}{l}\text { Показник математичної статистики } \\
\text { рядів розподілу }\end{array}$} \\
\hline & & 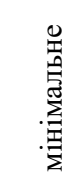 & 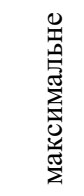 & 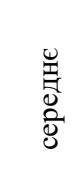 & $\begin{array}{l}\frac{\pi}{\sigma} \\
\frac{0}{2}\end{array}$ & 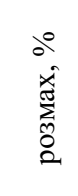 & 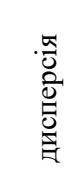 & 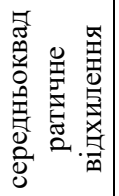 & 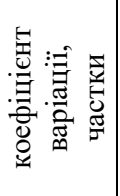 & 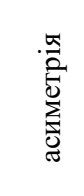 & $\begin{array}{l}0 \\
\ddot{0} \\
\stackrel{0}{0}\end{array}$ \\
\hline & $n_{\mathrm{m}}$ & $m_{\min }$ & $m_{\max }$ & $\bar{m}$ & $M_{\mathrm{m}}$ & $R_{\mathrm{m}}$ & $D_{\mathrm{m}}$ & $\sigma_{\mathrm{m}}$ & $k_{\mathrm{B}}$ & $A_{\mathrm{S}}$ & $E_{\mathrm{K}}$ \\
\hline \multicolumn{12}{|c|}{ Пласти полого залягання } \\
\hline $\mathrm{I}$ & 100 & 0,45 & 2,00 & 0,84 & 0,70 & 1,55 & 0,05 & 0,231 & 0,28 & 0,68 & $-0,27$ \\
\hline II & 204 & 0,43 & 3,00 & 0,93 & 0,70 & 2,67 & 0,09 & 0,296 & 0,32 & 1,27 & 2,00 \\
\hline III & 143 & 0,40 & 2,60 & 1,04 & 0,90 & 2,20 & 0,13 & 0,356 & 0,34 & 1,11 & 1,17 \\
\hline IV & 143 & 0,41 & 2,80 & 0,96 & 0,90 & 2,39 & 0,11 & 0,324 & 0,34 & 1,31 & 3,15 \\
\hline $\mathrm{V}$ & 170 & 0,40 & 2,11 & 1,01 & 0,70 & 1,71 & 0,11 & 0,324 & 0,32 & 0,77 & 0,25 \\
\hline VI & 99 & 0,48 & 2,50 & 1,05 & 1,10 & 2,02 & 0,09 & 0,308 & 0,29 & 0,65 & 0,74 \\
\hline VII & 65 & 0,31 & 3,00 & 1,10 & 1,00 & 2,69 & 0,13 & 0,355 & 0,32 & 1,25 & 1,79 \\
\hline VIII & 52 & 0,60 & 2,24 & 1,16 & 0,90 & 1,84 & 0,12 & 0,352 & 0,30 & 0,96 & 1,35 \\
\hline \multicolumn{12}{|c|}{ Пласти крутопадаючого залягання } \\
\hline I & 37 & 0,35 & 1,67 & 0,69 & 0,50 & 1,62 & 0,07 & 0,260 & 0,38 & 1,70 & 4,25 \\
\hline II & 221 & 0,35 & 1,52 & 0,65 & 0,50 & 1,17 & 0,03 & 0,172 & 0,27 & 1,41 & 3,42 \\
\hline III & 123 & 0,38 & 2,00 & 0,75 & 0,70 & 1,62 & 0,06 & 0,249 & 0,33 & 1,23 & 2,18 \\
\hline IV & 109 & 0,37 & 2,10 & 1,01 & 0,90 & 1,73 & 0,11 & 0,334 & 0,33 & 0,43 & 0,18 \\
\hline $\mathrm{V}$ & 37 & 0,40 & 2,05 & 1,09 & 1,10 & 1,65 & 0,16 & 0,399 & 0,37 & 0,45 & $-0,06$ \\
\hline VI & 9 & 0,60 & 1,99 & 1,12 & - & 1,39 & 0,16 & 0,397 & 0,36 & $-0,21$ & $-1,58$ \\
\hline VII & 4 & 0,83 & 1,50 & 0,96 & - & 0,67 & 0,04 & 0,191 & 0,20 & 1,97 & 3,91 \\
\hline VIII & 3 & 0,62 & 1,44 & 0,93 & - & 0,82 & 0,08 & 0,276 & 0,30 & $-0,98$ & - \\
\hline IX* & 197 & 0,35 & 4,50 & 0,90 & 0,75 & 4,15 & 0,15 & 0,381 & 0,42 & 3,22 & 19,06 \\
\hline $\mathrm{X}^{* * *}$ & 5 & 0,40 & 0,70 & 0,56 & - & 0,30 & 0,01 & 0,110 & 0,20 & $-0,30$ & $-0,23$ \\
\hline
\end{tabular}

Примітка: *, ** - див. табл. 4

Вологість вугілля $\left(W^{t}\right)$, як і вихід летких речовин $\left(V^{\text {daf }}\right)$, належить до одного з показників ступеня метаморфічних перетворень шахтопластів. Гістограми розподілу шахтопластів за цими показниками, якщо порівнювати графіки рисунків 2 і 4, істотно різняться. Характер розподілу шахтопластів пологого та крутопадаючого залягання за фактором $W^{t}$ (рис. 4), на відміну від розподілу за показником $V^{\text {daf }}$ (рис. 2), має приблизно однакову спрямованість. Це зайвий раз вказує на те, що $W^{t}$ та $V^{\text {daf }}$ характеризують різні аспекти метаморфічних перетворень вугільних шахтопластів.

Крайні значення параметрів статистичних моделей потужності (m)

Таблиияя 8 в сукупності їх груп за пилоутворювальною здатністю шахтопластів Донбасу та Львівсько-Волинського басейну згідно з «Каталогом...» [4]

\begin{tabular}{|c|c|c|c|c|c|c|c|c|c|c|c|c|c|c|c|c|c|c|c|c|}
\hline \multirow{4}{*}{$\begin{array}{c}\text { Залягання } \\
\text { пластів }\end{array}$} & \multicolumn{20}{|c|}{ Значення параметрів $m$ у виборці груп шахтопластів за їх пиловим фактором, \% } \\
\hline & \multicolumn{4}{|c|}{$m_{\min }$} & \multicolumn{4}{|c|}{$m_{\max }$} & \multicolumn{4}{|c|}{$R_{\mathrm{m}}$} & \multicolumn{4}{|c|}{$\bar{m}$} & \multicolumn{4}{|c|}{$M_{\mathrm{m}}$} \\
\hline & \multicolumn{2}{|c|}{$\min$} & \multicolumn{2}{|c|}{$\max$} & \multicolumn{2}{|c|}{$\min$} & \multicolumn{2}{|c|}{$\max$} & \multicolumn{2}{|c|}{$\min$} & \multicolumn{2}{|c|}{$\max$} & \multicolumn{2}{|c|}{$\min$} & \multicolumn{2}{|c|}{$\max$} & \multicolumn{2}{|c|}{$\min$} & \multicolumn{2}{|c|}{$\max$} \\
\hline & $\Xi$ & है & $\Xi$ & 嗂 & $\Xi$ & 㞼 & $\Xi$ & 絰 & $ミ$ & 㞼 & $\Xi$ & 㞼 & $\Xi$ & 胥 & $\Xi$ & 胥 & $\Xi$ & 胥 & $\Xi$ & 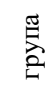 \\
\hline Пологе & 0,31 & VII & 0,60 & VIII & 2,00 & I & 3,00 & $\begin{array}{c}\text { II, } \\
\text { VII }\end{array}$ & 1,55 & I & 2,69 & VII & 0,84 & I & 1,16 & VIII & 0,70 & $\begin{array}{c}\text { I, II, } \\
\text { V }\end{array}$ & 1,10 & VI \\
\hline Крутопадаюче & 0,35 & I, II & 0,83 & VII & 1,44 & VIII & 2,10 & IV & 0,67 & VII & 1,73 & IV & 0,65 & II & 1,12 & VI & 0,50 & I, II & 1,10 & $\mathrm{~V}$ \\
\hline
\end{tabular}

Істотної різниці в характері розподілу шахтопластів пологого та крутопадаючого залягання Донбасу i Львівсько-Волинського басейну за критерієм $W^{t}$ не спостерігається (рис. 4,6 ). Поряд з цим шахтопласти 
пологого залягання характеризуються більш високою середньою і максимальною вологістю (табл. 9). Таке співвідношення між показниками вологи збереглося і для всіх груп по запиленості шахтопластів 3 I по VIII (табл. 10). Це вказує на те, що за інших рівних умов шахтопласти крутопадаючого падіння за критерієм $W^{t}$ більш схильні до підвищеного пилоутворення.
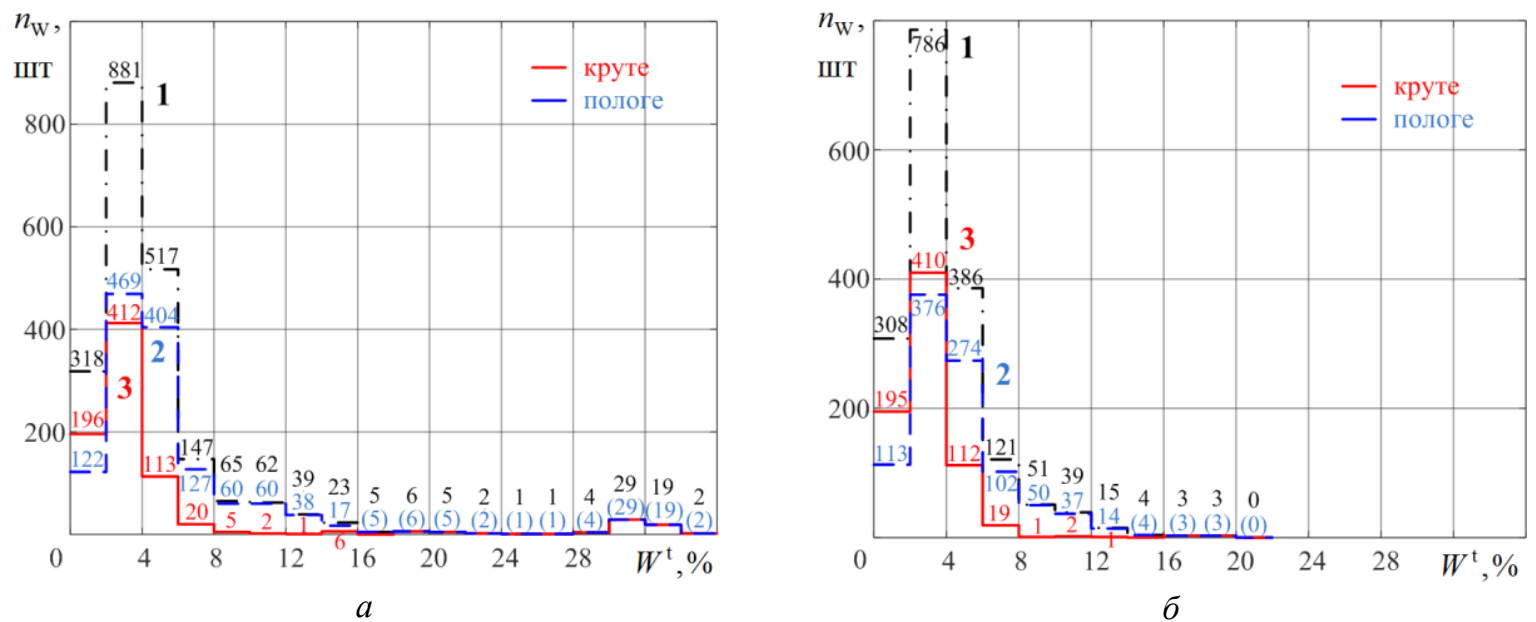

Рис. 4. Гістограми розподілу шахтопластів всіх вугільних родовищ (а) та Донбасу спільно з Львівсько-

Волинським басейном (б) за вологістю $\left(W^{t}\right)$ згідно з «Каталогом...» [4]

(1 - гістограми сумарного розподілу шахтопластів пологого та крутопадаючого залягання;

2,3 - гістограми розподілу шахтопластів відповідно пологого та крутопадаючого залягання; $\underline{318}$ - кількість шахтопластів $\left(n_{W}\right)$ в окремому інтервалі зміни $\left.W^{t}\right)$

Одним із підтверджуючих фактів приналежності вологості вугілля $\left(W^{t}\right)$ до одного 3 основних показників пилоутворювальної здатності шахтопластів $є$ відомості про параметри статистичних моделей $W_{\min }^{\mathrm{t}}, \quad W_{\max }^{\mathrm{t}}, R_{\mathrm{W}}, \bar{W}^{\mathrm{t}}$ i $M_{\mathrm{W}}$ (табл. 11). За цими показниками здебільшого групи запиленості шахтопластів пологого і крутопадаючого залягання збігаються.

Вміст пилу у відбитому вугіллі $(N) \in$ одним із основних показників метаморфічних перетворень шахтопластів при їх градації на групи за пиловим фактором. Ця обставина підтверджується як схожими графіками гістограм розподілу $N$ (рис. 5) та $q$ (рис. 6), так і методикою розрахунку $q$ відповідно до рівняння (1), з використанням значення $N$. Такі обставини зумовлюють високий кореляційний взаємозв'язок між $N$ та $q$.

Таблиця 9

Показники статистичних моделей розподілу варіанта вологості вугілля $\left(W^{t}\right)$ при групуванні шахтопластів за пиловим фактором згідно з «Каталогом...» [4]

\begin{tabular}{|c|c|c|c|c|c|c|c|c|c|c|c|c|c|c|}
\hline \multirow[b]{2}{*}{ 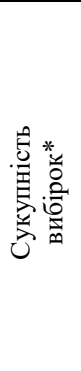 } & \multirow[b]{2}{*}{ 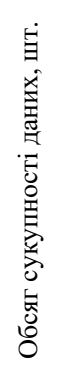 } & \multicolumn{3}{|c|}{$\begin{array}{c}\text { Значення } W^{t} \text { у } \\
\text { вибірках, \% }\end{array}$} & \multicolumn{8}{|c|}{$\begin{array}{l}\text { Показник математичної статистики } \\
\text { рядів розподілу }\end{array}$} & \multicolumn{2}{|c|}{ Критерій Пірсона } \\
\hline & & 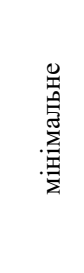 & 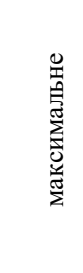 & 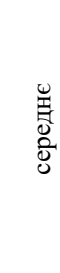 & $\begin{array}{l}\frac{\pi}{4} \\
\text { 일 }\end{array}$ & 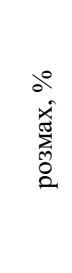 & 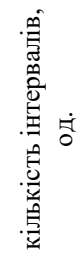 & 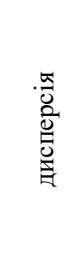 & 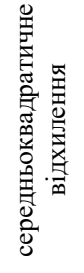 & 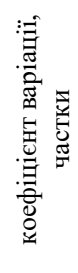 & 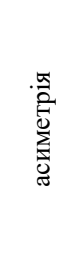 & $\begin{array}{l}\text { Uू } \\
\stackrel{0}{0} \\
\ddot{y}\end{array}$ & 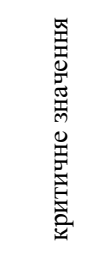 & 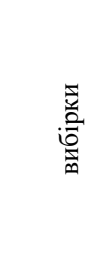 \\
\hline$*$ & $n_{\mathrm{W}}$ & $W_{\min }^{\mathrm{t}}$ & $W_{\max }^{\mathrm{t}}$ & $\bar{W}^{\mathrm{t}}$ & $M_{\mathrm{W}}$ & $R_{\mathrm{W}}$ & $k^{\mathrm{W}}$ & $D_{\mathrm{W}}$ & $\sigma_{\mathrm{W}}$ & $k_{\mathrm{B}}$ & $A_{\mathrm{S}}$ & $E_{\mathrm{K}}$ & $\chi_{\mathrm{\kappa p}}^{2}$ & $\chi_{\mathrm{B}}^{2}$ \\
\hline 1 & 2126 & 0,2 & 34,5 & 5,2 & 3,0 & 34,3 & 18 & 28,5 & 5,34 & 1,03 & 3,59 & 14,57 & 24,996 & $1,3 \times 10^{6}$ \\
\hline 2 & 1371 & 0,2 & 34,5 & 6,3 & 3,0 & 34,3 & 18 & 38,9 & 6,24 & 0,99 & 2,98 & 9,27 & 24,996 & $3,4 \times 10^{4}$ \\
\hline 3 & 755 & 0,6 & 14,2 & 3,1 & 3,0 & 13,6 & 8 & 3,2 & 1,78 & 0,57 & 2,88 & 13,13 & 21,096 & $1,5 \times 10^{8}$ \\
\hline 4 & 1727 & 0,2 & 22,5 & 3,9 & 3,0 & 22,3 & 12 & 5,8 & 2,41 & 0,62 & 2,22 & 7,15 & 31,410 & $6,1 \times 10^{6}$ \\
\hline 5 & 982 & 0,2 & 22,5 & 4,5 & 3,0 & 22,3 & 12 & 7,7 & 2,77 & 0,61 & 1,88 & 4,69 & 31,410 & $2,5 \times 10^{4}$ \\
\hline 6 & 445 & 0,6 & 12,2 & 3,0 & 3,0 & 11,6 & 7 & 2,0 & 1,41 & 0,47 & 1,71 & 5,94 & 18,307 & $3,4 \times 10^{7}$ \\
\hline
\end{tabular}


Таблиия 10

Статистичні моделі розподілу шахтопластів Донбасу і Львівсько-Волинського басейну по вологості вугілля $\left(W^{t}\right)$ при визначенні груп пилоутворювальної здатності згідно з «Каталогом...» [4]

\begin{tabular}{|c|c|c|c|c|c|c|c|c|c|c|c|}
\hline \multirow[b]{2}{*}{ 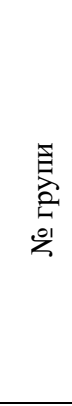 } & \multirow[b]{2}{*}{ 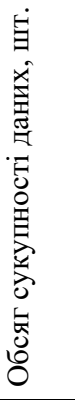 } & \multicolumn{3}{|c|}{$\begin{array}{c}\text { Значення } W^{\mathrm{t}} \mathrm{y} \\
\text { вибірках, \% }\end{array}$} & \multicolumn{7}{|c|}{$\begin{array}{c}\text { Показник математичної статистики } \\
\text { рядів розподілу }\end{array}$} \\
\hline & & 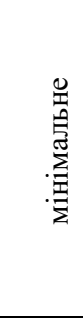 & 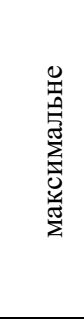 & 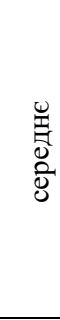 & 氶 & 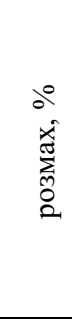 & 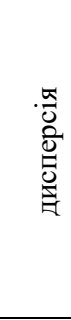 & 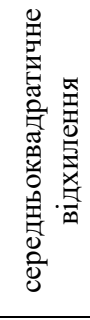 & 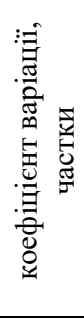 & 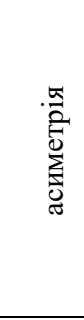 & 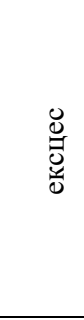 \\
\hline & $n_{\mathrm{W}}$ & $W_{\min }^{\mathrm{t}}$ & $W_{\max }^{\mathrm{t}}$ & $\bar{W}^{\mathrm{t}}$ & $M_{\mathrm{W}}$ & $R_{\mathrm{W}}$ & $D_{\mathrm{W}}$ & $\sigma_{\mathrm{W}}$ & $k_{\text {в }}$ & $A_{\mathrm{S}}$ & $E_{\mathrm{K}}$ \\
\hline \multicolumn{12}{|c|}{ Пласти полого залягання } \\
\hline $\mathrm{I}$ & 100 & 1,4 & 22,5 & 7,2 & 3,0 & 21,1 & 19,4 & 4,40 & 0,61 & 1,02 & 0,11 \\
\hline II & 204 & 0,9 & 16,7 & 5,2 & 3,5 & 15,8 & 8,4 & 2,89 & 0,56 & 1,09 & 1,20 \\
\hline III & 143 & 0,9 & 17,8 & 4,0 & 3,5 & 16,9 & 7,3 & 2,70 & 0,54 & 1,26 & 2,19 \\
\hline IV & 143 & 0,7 & 12,0 & 4,1 & 3,5 & 11,3 & 5,0 & 2,24 & 0,55 & 1,53 & 2,72 \\
\hline $\mathrm{V}$ & 170 & 0,2 & 10,7 & 3,4 & 3,5 & 10,5 & 2,5 & 1,58 & 0,46 & 0,98 & 3,03 \\
\hline VI & 99 & 0,9 & 8,0 & 3,4 & 4,5 & 7,1 & 1,6 & 1,28 & 0,38 & $-0,10$ & $-1,02$ \\
\hline VII & 65 & 0,8 & 6,7 & 3,5 & 3,25 & 5,9 & 1,3 & 1,15 & 0,33 & $-0,18$ & $-0,20$ \\
\hline VIII & 52 & 0,7 & 6,1 & 3,5 & 4,75 & 5,4 & 1,4 & 1,20 & 0,34 & $-0,28$ & $-0,36$ \\
\hline \multicolumn{12}{|c|}{ Пласти крутопадаючого залягання } \\
\hline I & 37 & 1,0 & 12,2 & 4,3 & 2,5 & 11,2 & 7,1 & 2,66 & 0,62 & 1,65 & 2,58 \\
\hline II & 221 & 0,9 & 10,3 & 3,2 & 2,5 & 9,4 & 1,6 & 1,27 & 0,40 & 1,12 & 1,71 \\
\hline III & 123 & 0,7 & 7,1 & 2,7 & 2,5 & 6,4 & 1,3 & 1,13 & 0,41 & 1,05 & 1,70 \\
\hline IV & 109 & 0,7 & 6,6 & 2,5 & 2,25 & 5,9 & 1,0 & 0,98 & 0,40 & 1,10 & 1,45 \\
\hline $\mathrm{V}$ & 37 & 0,6 & 5,2 & 2,5 & 1,75 & 4,6 & 1,5 & 1,21 & 0,49 & 0,73 & $-0,38$ \\
\hline VI & 9 & 1,4 & 5,9 & 3,1 & - & 4,5 & 1,7 & 1,30 & 0,41 & $-0,19$ & $-1,89$ \\
\hline VII & 4 & 1,5 & 3,8 & 2,5 & - & 2,3 & 1,2 & 1,11 & 0,45 & 0,48 & $-3,25$ \\
\hline VIII & 3 & 1,3 & 4,6 & 2,5 & - & 3,3 & 2,8 & 1,68 & 0,67 & 1,70 & - \\
\hline IX* & 197 & 0,7 & 10,0 & 3,0 & 2,5 & 9,3 & 2,0 & 1,43 & 0,47 & 1,15 & 2,27 \\
\hline $\mathrm{X}^{* * *}$ & 5 & 1,1 & 6,3 & 3,6 & - & 5,2 & 3,6 & 1,90 & 0,52 & 0,75 & $-1,42$ \\
\hline
\end{tabular}

Таблиия 11

Крайні значення параметрів статистичних моделей вологості вугілля (Wt) в сукупності їх груп за пилоутворювальною здатністю шахтопластів Донбасу та Львівсько-Волинського басейну згідно $з$ «Каталогом...» [4]

\begin{tabular}{|c|c|c|c|c|c|c|c|c|c|c|c|c|c|c|c|c|c|c|c|c|}
\hline \multirow{4}{*}{$\begin{array}{c}\text { Залягання } \\
\text { пластів }\end{array}$} & \multicolumn{20}{|c|}{ Значення параметрів $W^{t}$ у виборці груп шахтопластів за їх пиловим фактором, \% } \\
\hline & \multicolumn{4}{|c|}{$W_{\min }^{\mathrm{t}}$} & \multicolumn{3}{|c|}{$W_{\max }^{\mathrm{t}}$} & \multicolumn{4}{|c|}{$R_{\mathrm{W}}$} & \multicolumn{5}{|c|}{$\bar{W}^{\mathrm{t}}$} & \multicolumn{4}{|c|}{$M_{\mathrm{W}}$} \\
\hline & \multicolumn{2}{|c|}{$\min$} & \multicolumn{2}{|c|}{$\max$} & \multicolumn{2}{|c|}{$\min$} & $\max$ & \multicolumn{2}{|c|}{$\min$} & \multicolumn{2}{|c|}{$\max$} & \multicolumn{3}{|c|}{$\min$} & \multicolumn{2}{|c|}{$\max$} & \multicolumn{2}{|c|}{$\min$} & \multicolumn{2}{|c|}{$\max$} \\
\hline & 5 & 营 & 3 & 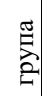 & 5 & 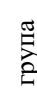 & 3 & 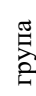 & 3 & 䍃 & 3 & 朐 & 5 & 䍃 & 3 & 㸒 & 3 & 䍃 & 3 & 苟 \\
\hline Пологе & ชै & $>$ & $\stackrel{\nabla}{=}$ & - & $\overline{0}$ & 目 & $\begin{array}{l}\tilde{N} \\
\tilde{N}\end{array}$ & - & $\stackrel{\vec{n}}{\dot{n}}$ & 辛 & $\vec{i}$ & - & $\dot{m}$ & $\begin{array}{l}5 \\
>\end{array}$ & $\stackrel{2}{2}$ & - & $\stackrel{\circ}{m}$ & - & 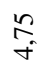 & 貝 \\
\hline Крутопадаюче & $\because$ & $>$ & $\cong$ & 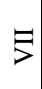 & $\stackrel{\infty}{m}$ & 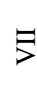 & $\tilde{I}$ & - & $\stackrel{\text { in }}{\mathrm{i}}$ & $\overline{5}$ & $\stackrel{\mathcal{I}}{=}$ & - & $\tilde{n}$ & $\underset{\substack{7 \\
>\\
>}}{J}$ & $\stackrel{m}{F}$ & - & $\stackrel{2}{=}$ & $>$ & $\tilde{n}$ & $\Xi$ \\
\hline
\end{tabular}



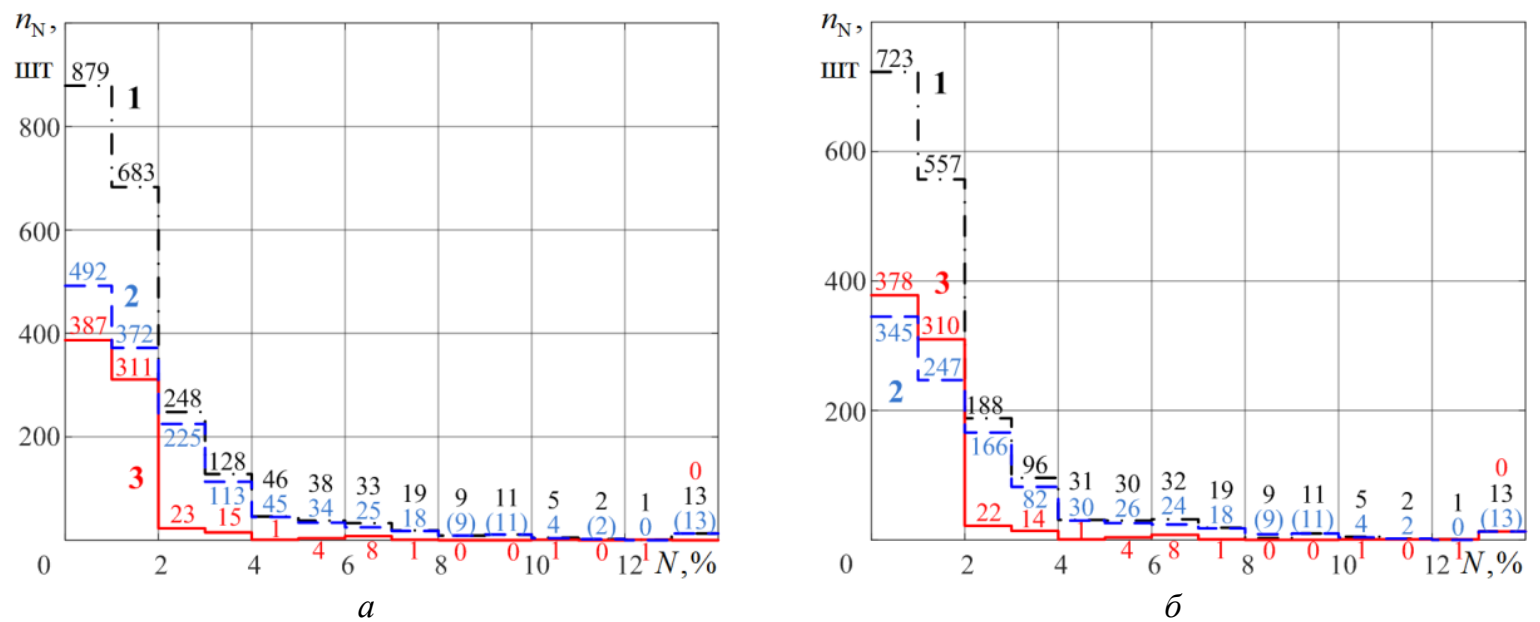

Рис. 5. Гістограми розподілу шахтопластів всіх вугільних родовищ (а) та Донбасу спільно з ЛьвівськоВолинським басейном (б) за вмістом пилу у відбитому вугіллі (N) згідно з «Каталогом...» [4] (1 - гістограми сумарного розподілу шахтопластів пологого та крутопадаючого залягання; $\mathbf{2 , 3}$ - гістограми розподілу шахтопластів відповідно пологого та крутопадаючого залягання; $\underline{879}$ - кількість шахтопластів $\left(n_{N}\right)$ в окремому інтервалі зміни $N$ )
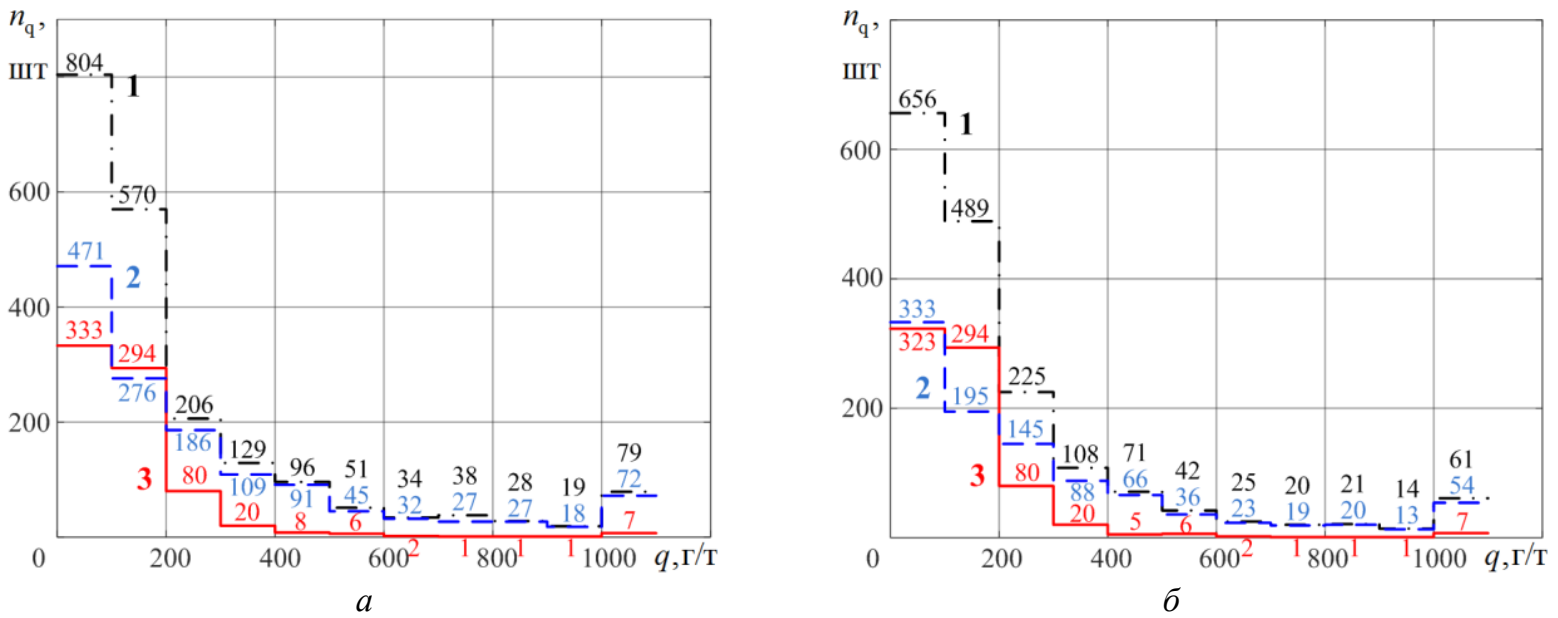

Рис. 6. Гістограми розподілу шахтопластів всіх вугільних родовищ (а) та Донбасу спільно з ЛьвівськоВолинським басейном (б) за питомим пиловиділенням (q) згідно з «Каталогом...» [4]

(1 - гістограми сумарного розподілу шахтопластів пологого та крутопадаючого залягання;

2, 3 - гістограми розподілу шахтопластів відповідно пологого та крутопадаючого залягання; $\underline{804}$ - кількість шахтопластів $\left(n_{N}\right)$ в окремому інтервалі зміни $N$ )

Показники статистичних моделей розподілу варіанта вмісту пилу у відбитому вугіллі $(N)$ при групуванні шахтопластів пологого та крутопадаючого залягання за пиловим фактором мають близькі між собою значення або вони однакові (табл. 12). Виняток становлять лише середні значення $\bar{N}$. Для пластів пологого залягання $\bar{N}=2,29 \%$ (вибірка № 5), а для крутопадаючих $\bar{N}=1,22 \%$ (вибірка № 6). Це свідчить про те, що в цілому середній вміст пилу у відбитому вугіллі на пластах крутопадаючого падіння майже в два рази нижче порівнянно 3 пологими пластами. 3 іншого боку, показники у всіх групах запиленості з I по VIII для шахтопластів пологого і крутопадаючого падіння мають близькі між собою значення (табл. 13). Відмінність середніх значень $\bar{N}$ за критерієм кута падіння пластів можна пояснити різною технологією виїмки вугілля на пластах пологого і крутопадаючого залягання. Відбій вугілля в очисних вибоях у розглянутий період часу на пластах пологого падіння проводився в основному за допомогою комбайнів та стругів, а на крутопадаючих пластах переважно за допомогою відбійних молотків. Інтенсивність руйнування вугілля і відділення його від вибою в першому випадку перевищують ці показники при технології виїмки вугілля відбійними молотками. 
Табличя 12

Показники статистичних моделей розподілу варіанта за вмістом пилу у відбитому вугіллі (N) при групуванні шахтопластів за пиловим фактором згідно з «Каталогом...» [4]

\begin{tabular}{|c|c|c|c|c|c|c|c|c|c|c|c|c|c|c|}
\hline \multirow[b]{2}{*}{ 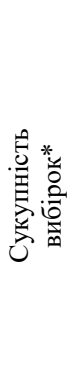 } & \multirow[b]{2}{*}{ 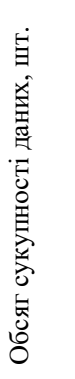 } & \multicolumn{3}{|c|}{$\begin{array}{l}\text { Значення } N \text { у } \\
\text { вибірках, \% }\end{array}$} & \multicolumn{8}{|c|}{$\begin{array}{c}\text { Показник математичної статистики } \\
\text { рядів розподілу }\end{array}$} & \multicolumn{2}{|c|}{ Критерій Пірсона } \\
\hline & & 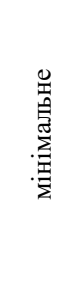 & 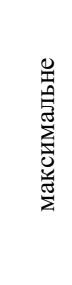 & 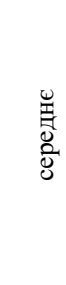 & $\begin{array}{l}\frac{\pi}{4} \\
\stackrel{2}{2}\end{array}$ & 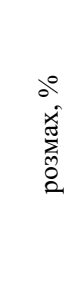 & 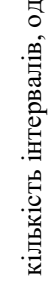 & 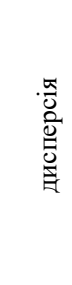 & 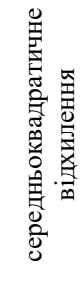 & 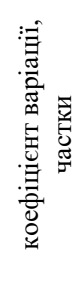 & 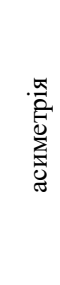 & 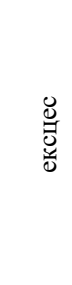 & 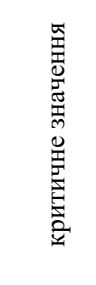 & 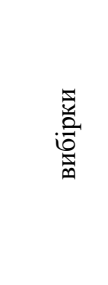 \\
\hline$*$ & $n_{\mathrm{N}}$ & $N_{\min }$ & $N_{\max }$ & $\bar{N}$ & $M_{\mathrm{W}}$ & $R_{\mathrm{N}}$ & $k^{\mathrm{N}}$ & $D_{\mathrm{N}}$ & $\sigma_{\mathrm{N}}$ & $k_{\mathrm{B}}$ & $A_{\mathrm{S}}$ & $E_{\mathrm{K}}$ & $\chi_{\text {кр }}^{2}$ & $\chi_{\mathrm{B}}^{2}$ \\
\hline 1 & 2115 & 0,09 & 13,43 & 1,80 & 0,50 & 13,34 & 14 & 3,59 & 1,894 & 1,05 & 3,09 & 12,10 & 19,675 & $7,3 \cdot 10^{7}$ \\
\hline 2 & 1363 & 0,09 & 13,43 & 2,13 & 0,50 & 13,34 & 14 & 4,68 & 2,164 & 1,02 & 2,56 & 8,20 & 19,675 & $6,7 \cdot 10^{5}$ \\
\hline 3 & 752 & 0,17 & 12,50 & 1,21 & 0,50 & 12,33 & 13 & 1,06 & 1,031 & 0,85 & 5,28 & 38,74 & 18,307 & $4,1 \cdot 10^{23}$ \\
\hline 4 & 1718 & 0,09 & 13,43 & 1,83 & 0,50 & 13,34 & 14 & 4,02 & 2,005 & 1,10 & 3,08 & 11,42 & 19,675 & $1,15 \cdot 10^{7}$ \\
\hline 5 & 976 & 0,09 & 13,43 & 2,29 & 0,50 & 13,34 & 14 & 5,76 & 2,408 & 1,05 & 2,37 & 6,48 & 36,415 & $7,10 \cdot 10^{4}$ \\
\hline 6 & 742 & 0,17 & 12,50 & 1,22 & 0,50 & 12,33 & 13 & 1,07 & 1,034 & 0,85 & 5,29 & 38,62 & 33,924 & $3,9 \cdot 10^{22}$ \\
\hline
\end{tabular}

Примітка: крок всіх інтервалів $\mathrm{h}_{\mathrm{N}}=1,0 ; *-$ див. табл. 3

Таблиия 13

Статистичні моделі розподілу шахтопластів Донбасу і Львівсько-Волинського басейну за вмістом пилу у відбитому вугіллі (N) при визначенні груп пилоутворювальної здатності згідно з «Каталогом...» [4]

\begin{tabular}{|c|c|c|c|c|c|c|c|c|c|c|c|}
\hline \multirow[b]{2}{*}{$\begin{array}{l}\text { 声 } \\
\text { 总 } \\
\text { 呪 }\end{array}$} & \multirow[b]{2}{*}{ 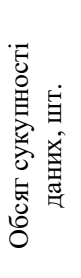 } & \multicolumn{3}{|c|}{ Значення $N$ у вибірках, \% } & \multicolumn{7}{|c|}{$\begin{array}{l}\text { Показник математичної статистики } \\
\text { рядів розподілу }\end{array}$} \\
\hline & & 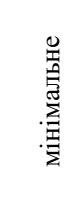 & 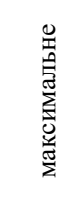 & 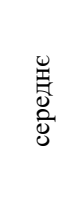 & $\frac{\pi}{2}$ & 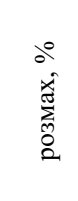 & 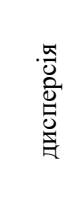 & 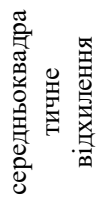 & 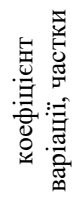 & 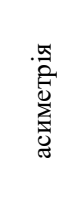 & 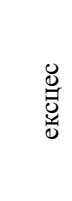 \\
\hline & $n_{\mathrm{N}}$ & $N_{\min }$ & $N_{\max }$ & $\bar{N}$ & $M_{\mathrm{W}}$ & $R_{\mathrm{N}}$ & $D_{\mathrm{N}}$ & $\sigma_{\mathrm{N}}$ & $k_{\mathrm{B}}$ & $A_{\mathrm{S}}$ & $E_{\mathrm{K}}$ \\
\hline \multicolumn{12}{|c|}{ Пласти полого залягання } \\
\hline I & 100 & 0,09 & 2,70 & 0,49 & 0,30 & 2,61 & 0,13 & 0,359 & 0,73 & 3,12 & 14,90 \\
\hline II & 204 & 0,24 & 1,57 & 0,76 & 0,75 & 1,33 & 0,07 & 0,260 & 0,34 & 0,80 & 0,83 \\
\hline III & 143 & 0,42 & 3,30 & 1,11 & 1,30 & 2,88 & 0,16 & 0,400 & 0,36 & 1,52 & 5,99 \\
\hline IV & 143 & 0,30 & 6,00 & 1,80 & 1,25 & 5,70 & 0,67 & 0,816 & 0,45 & 1,71 & 4,98 \\
\hline $\mathrm{V}$ & 170 & 0,44 & 6,30 & 2,39 & 2,25 & 5,86 & 0,65 & 0,804 & 0,34 & 1,14 & 4,06 \\
\hline VI & 99 & 1,40 & 9,50 & 3,65 & 3,50 & 8,1 & 1,81 & 1,347 & 0,37 & 1,42 & 2,94 \\
\hline VII & 65 & 2,05 & 10,20 & 5,53 & 4,50 & 8,15 & 2,85 & 1,689 & 0,31 & 0,27 & $-0,07$ \\
\hline VIII & 52 & 0,55 & 13,43 & 9,42 & 8,50 & 12,88 & 8,96 & 2,994 & 0,32 & $-0,30$ & 0,11 \\
\hline \multicolumn{12}{|c|}{ Пласти крутопадаючого залягання } \\
\hline $\mathrm{I}$ & 37 & 0,17 & 1,04 & 0,57 & 0,45 & 0,87 & 0,05 & 0,222 & 0,39 & 0,30 & $-0,81$ \\
\hline II & 221 & 0,36 & 1,73 & 0,84 & 0,70 & 1,37 & 0,05 & 0,234 & 0,28 & 0,92 & 0,85 \\
\hline III & 123 & 0,38 & 2,56 & 1,15 & 1,10 & 2,18 & 0,12 & 0,346 & 0,30 & 1,19 & 2,58 \\
\hline IV & 109 & 0,78 & 3,70 & 1,31 & 1,05 & 2,92 & 0,24 & 0,489 & 0,37 & 3,02 & 10,47 \\
\hline $\mathrm{V}$ & 37 & 0,50 & 5,50 & 2,03 & 1,25 & 5,00 & 0,99 & 0,995 & 0,49 & 1,48 & 2,82 \\
\hline VI & 9 & 1,00 & 6,80 & 3,71 & - & 5,80 & 4,08 & 2,020 & 0,54 & 0,27 & $-1,59$ \\
\hline VII & 4 & 1,20 & 6,50 & 4,95 & - & 5,30 & 6,34 & 2,517 & 0,51 & $-1,92$ & 3,71 \\
\hline VIII & 3 & 6,30 & 12,50 & 9,93 & - & 6,20 & 10,46 & 2,235 & 0,33 & $-1,32$ & - \\
\hline IX* & 197 & 0,41 & 7,50 & 1,26 & 0,50 & 7,09 & 1,06 & 1,030 & 0,82 & 3,88 & 17,00 \\
\hline $\mathrm{X}^{* *}$ & 2 & 2,35 & 3,85 & 3,10 & - & 1,50 & 1,13 & 1,060 & 0,34 & - & - \\
\hline
\end{tabular}

Примітка: *, **-див. табл. 4 
Крайні значення параметрів статистичних моделей вмісту пилу у відбитому вугіллі $\left(N_{\min }, N_{\max }, R_{\mathrm{N}}\right.$, $\bar{N}$ і $M_{\mathrm{N}}$ ) практично збігаються між собою для пологих та крутопадаючих пластів (табл. 14). Це вказує на досить високий кореляційний зв'язок між $N$ та $q$.

Таблиия 14

Крайні значення параметрів статистичних моделей вмісту пилу у відбитому вугіллі (N) в сукупності їх груп за пилоутворювальною здатністю шахтопластів Донбасу та Львівсько-Волинського басейну згідно з «Каталогом...» [4]

\begin{tabular}{|c|c|c|c|c|c|c|c|c|c|c|c|c|c|c|c|c|c|c|c|c|}
\hline \multirow{4}{*}{$\begin{array}{c}\text { Залягання } \\
\text { пластів }\end{array}$} & \multicolumn{20}{|c|}{ Значення параметрів $N$ в виборці груп шахтопластів за їх пиловим фактором, \% } \\
\hline & \multicolumn{4}{|c|}{$N_{\min }$} & \multicolumn{4}{|c|}{$N_{\max }$} & \multicolumn{4}{|c|}{$R_{\mathrm{N}}$} & \multicolumn{4}{|c|}{$\bar{N}$} & \multicolumn{4}{|c|}{$M_{\mathrm{N}}$} \\
\hline & \multicolumn{2}{|c|}{$\min$} & \multicolumn{2}{|c|}{$\max$} & \multicolumn{2}{|c|}{$\min$} & \multicolumn{2}{|c|}{$\max$} & \multicolumn{2}{|c|}{$\min$} & \multicolumn{2}{|c|}{$\max$} & \multicolumn{2}{|c|}{$\min$} & \multicolumn{2}{|c|}{$\max$} & \multicolumn{2}{|c|}{$\min$} & \multicolumn{2}{|c|}{$\max$} \\
\hline & $z$ & 舀 & $z$ & $\begin{array}{l}\stackrel{\pi}{2} \\
\stackrel{2}{2} \\
0\end{array}$ & $z$ & 㲧 & $z$ & 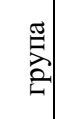 & $z$ & 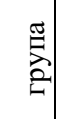 & $z$ & 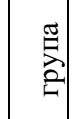 & $z$ & 舀 & $z$ & 胥 & $z$ & $\begin{array}{l}\stackrel{\pi}{2} \\
\stackrel{2}{2}\end{array}$ & $z$ & $\begin{array}{l}\text { 节 } \\
\text { 足 }\end{array}$ \\
\hline Пологе & 0,09 & I & 2,05 & VII & 1,57 & II & 13,4 & VIII & 1,33 & II & 12,88 & VIII & 0,49 & I & 9,42 & VIII & 0,30 & I & 8,50 & VIII \\
\hline Крутопадаюче & 0,17 & I & 6,30 & VIII & 1,04 & I & 12,5 & VIII & 0,87 & I & 6,2 & VIII & 0,57 & I & 9,93 & VIII & 0,45 & I & 1,25 & $\mathrm{~V}^{*}$ \\
\hline
\end{tabular}

Практично всі показники статистичних моделей розподілу варіанта питомого пиловиділення $(q)$ для шахтопластів пологого та крутопадаючого залягання близькі між собою за абсолютними значеннями (табл. 15). Тільки одним винятком з цього правила $є$ середні значення $\bar{q}$. Для шахтопластів пологого залягання Донбасу та Львівсько-Волинського басейну $\bar{q}=301,3$ (вибірка № 5), а для крутопадаючих пластів Донбасу $\bar{q}=146,2$ г/т (вибірка № 6). Це як і в випадку з показником $\bar{N}$ таке співвідношення вказує на вплив різної інтенсивності відбою вугілля на пилоутворювальну здатність шахтопластів.

У всіх групах запиленості шахтопластів пологого та крутопадаючого залягання статичні моделі за критерієм $q$ близькі між собою (табл. 16). Це свідчить про відсутність практичного впливу на пилоутворювальну здатність шахтопластів кутів їх залягання, що додатково підтверджується узгодженістю крайніх значень параметрів статистичних моделей (табл. 17).

Таблиия 15

Показники статистичних моделей розподілу варіанта питомого пиловиділення (q) при групуванні шахтопластів за пиловим фактором згідно з «Каталогом...» [4]

\begin{tabular}{|c|c|c|c|c|c|c|c|c|c|c|c|c|c|c|}
\hline \multirow[b]{2}{*}{ 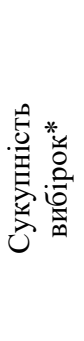 } & \multirow[b]{2}{*}{ 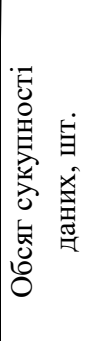 } & \multicolumn{3}{|c|}{$\begin{array}{l}\text { Значення } q \text { у } \\
\text { вибірках, г/т }\end{array}$} & \multicolumn{8}{|c|}{$\begin{array}{c}\text { Показники математичної статистики } \\
\text { рядів розподілу }\end{array}$} & \multicolumn{2}{|c|}{$\begin{array}{c}\text { Критерій } \\
\text { Пірсона } \\
\end{array}$} \\
\hline & & 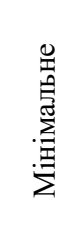 & 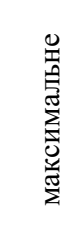 & 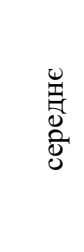 & $\begin{array}{l}\text { đ] } \\
\stackrel{0}{\Sigma}\end{array}$ & 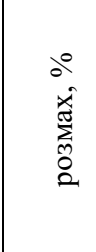 & 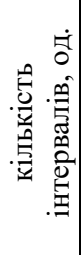 & $\begin{array}{l}\frac{\pi}{0} \\
0 \\
0 \\
0 \\
0 \\
0 \\
0\end{array}$ & 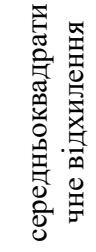 & 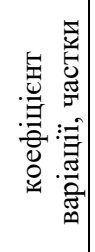 & 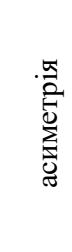 & $\begin{array}{l}0 \\
\ddot{0} \\
\tilde{y}\end{array}$ & 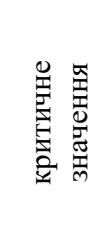 & 宽 \\
\hline$*$ & $n_{\mathrm{q}}$ & $q_{\min }$ & $q_{\max }$ & $\bar{q}$ & $M_{\mathrm{q}}$ & $R_{\mathrm{q}}$ & $k^{\mathrm{q}}$ & $D_{\mathrm{q}}$ & $\sigma_{\mathrm{q}}$ & $k_{\mathrm{B}}$ & $A_{\mathrm{S}}$ & $E_{\mathrm{K}}$ & $\chi_{\text {кр }}^{2}$ & $\chi_{\mathrm{B}}^{2}$ \\
\hline 1 & 2114 & 1,0 & 2700 & 244,2 & 50 & 2699 & 27 & 94246 & 307,0 & 1,26 & 3,08 & 12,70 & 36,415 & $\begin{array}{l}3,2 \\
10^{11}\end{array}$ \\
\hline 2 & 1364 & 1,0 & 2700 & 299,0 & 50 & 2699 & 27 & 127007 & 356,4 & 1,19 & 2,52 & 8,44 & 36,415 & $7,5 \cdot 10^{7}$ \\
\hline 3 & 750 & 12,0 & 2400 & 144,6 & 50 & 2388 & 24 & 19341 & 139,1 & 0,96 & 4,75 & 29,63 & 32,671 & $\begin{array}{l}9,6 \cdot \\
10^{13}\end{array}$ \\
\hline 4 & 1716 & 2,5 & 2700 & 234,4 & 50 & 2697,5 & 27 & 85868 & 293,0 & 1,25 & 3,54 & 16,9 & 36,415 & $\begin{array}{l}9,8 \\
10^{12}\end{array}$ \\
\hline 5 & 976 & 2,5 & 2700 & 301,3 & 50 & 2697,5 & 27 & 125952 & 355,0 & 1,18 & 2,82 & 10,6 & 36,415 & $\begin{array}{c}1,19 \\
10^{8}\end{array}$ \\
\hline 6 & 740 & 14,0 & 2400 & 146,2 & 50 & 2386 & 24 & 19398 & 139,0 & 0,85 & 4,76 & 29,6 & 32,671 & $\begin{array}{l}7,8 \\
10^{13}\end{array}$ \\
\hline
\end{tabular}

Примітка: крок усіх інтервалів $\mathrm{h}_{\mathrm{q}}=100$ г/т; * - див. табл. 3 
Таблиия 16

Статистичні моделі розподілу шахтопластів Донбасу і Львівсько-Волинського басейну за питомим пиловиділенням (q) при визначенні груп пилоутворювальної здатності згідно з «Каталогом...» [4]

\begin{tabular}{|c|c|c|c|c|c|c|c|c|c|c|c|}
\hline \multirow[b]{2}{*}{ 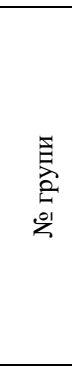 } & \multirow[b]{2}{*}{ 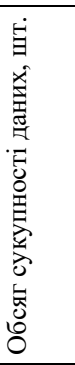 } & \multicolumn{3}{|c|}{$\begin{array}{l}\text { Значення } N \text { у } \\
\text { вибірках, г/т }\end{array}$} & \multicolumn{7}{|c|}{$\begin{array}{l}\text { Показник математичної статистики } \\
\text { рядів розподілу }\end{array}$} \\
\hline & & 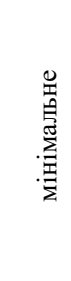 & 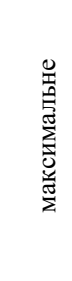 & 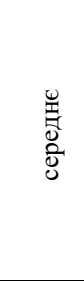 & 焉 & 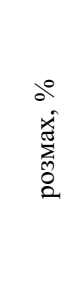 & 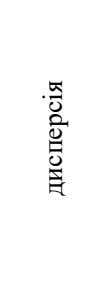 & 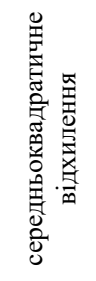 & 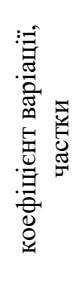 & 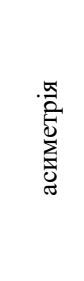 & 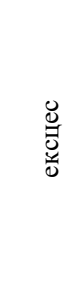 \\
\hline & $n_{\mathrm{q}}$ & $q_{\min }$ & $q_{\max }$ & $\bar{q}$ & $M_{\mathrm{q}}$ & $R_{\mathrm{q}}$ & $D_{\mathrm{q}}$ & $\sigma_{\mathrm{q}}$ & $k_{\mathrm{B}}$ & $A_{\mathrm{S}}$ & $E_{\mathrm{K}}$ \\
\hline \multicolumn{12}{|c|}{ Пласти полого залягання } \\
\hline I & 100 & 2,54 & 55 & 32,6 & 42,5 & 52,5 & 145 & 12,1 & 0,37 & $-0,35$ & $-0,60$ \\
\hline II & 204 & 35,0 & 150 & 75,1 & 60,0 & 115 & 253 & 15,9 & 0,21 & 0,59 & 1,35 \\
\hline III & 143 & 102 & 150 & 126,2 & 125,0 & 48 & 203 & 14,2 & 0,11 & 0,16 & $-0,99$ \\
\hline IV & 143 & 155 & 250 & 199,0 & 195,0 & 95 & 758 & 27,5 & 0,14 & 0,14 & $-1,00$ \\
\hline $\mathrm{V}$ & 170 & 225 & 725 & 315,8 & 275,0 & 500 & 2823 & 53,1 & 0,17 & 2,88 & 19,47 \\
\hline VI & 99 & 250 & 980 & 496,1 & 450,0 & 730 & 7762 & 88,1 & 0,18 & 1,72 & 9,46 \\
\hline VII & 65 & 602 & 1000 & 793,2 & 750,0 & 398 & 13468 & 116,1 & 0,15 & $-0,02$ & $-1,15$ \\
\hline VIII & 52 & 602 & 2700 & 1434,8 & 1100,0 & 2098 & 208364 & 456,5 & 0,32 & 1,22 & 0,92 \\
\hline \multicolumn{12}{|c|}{ Пласти крутопадаючого залягання } \\
\hline I & 37 & 14 & 65 & 37,5 & 42,5 & 51 & 68,5 & 8,3 & 0,22 & 0,13 & 0,93 \\
\hline II & 221 & 37 & 150 & 75,7 & 75 & 113 & 198 & 14,1 & 0,19 & 0,36 & 0,49 \\
\hline III & 123 & 75 & 175 & 125,5 & 130 & 100 & 200 & 14,2 & 0,11 & $-0,02$ & $-0,66$ \\
\hline IV & 109 & 125 & 290 & 189,7 & 170 & 165 & 718 & 26,8 & 0,14 & 0,22 & $-0,66$ \\
\hline $\mathrm{V}$ & 37 & 200 & 450 & 299,3 & 275 & 250 & 1609 & 40,1 & 0,13 & 0,66 & 0,02 \\
\hline VI & 9 & 201 & 670 & 464,8 & - & 469 & 12037 & 109,7 & 0,24 & $-1,73$ & 3,49 \\
\hline VII & 4 & 650 & 950 & 803,0 & - & 300 & 10999 & 104,9 & 0,13 & \begin{tabular}{|c|}
$-0,31$ \\
\end{tabular} & 1,23 \\
\hline VIII & 3 & 250 & 2400 & 1218,3 & - & 2150 & 1663,3 & 129,0 & 0,11 & $-1,18$ & - \\
\hline IX* & 197 & 23 & 1500 & 161,6 & 75 & 1477 & 26376 & 162,4 & 1,01 & 4,61 & 23,93 \\
\hline
\end{tabular}

Таблиия 17

Крайні значення параметрів статистичних моделей питомого пиловиділення (q) у сукупності їх груп за пилоутворювальною здатністю шахтопластів Донбасу та Львівсько-Волинського басейну згідно з «Каталогом...» [4]

\begin{tabular}{|c|c|c|c|c|c|c|c|c|c|c|c|c|c|c|c|c|c|c|c|c|}
\hline \multirow{4}{*}{$\begin{array}{c}\text { Залягання } \\
\text { пластів }\end{array}$} & \multicolumn{20}{|c|}{ Значення параметрів $q$ у виборці груп шахтопластів за їх пиловим фактором, г/т } \\
\hline & \multicolumn{4}{|c|}{$q_{\min }$} & \multicolumn{4}{|c|}{$q_{\max }$} & \multicolumn{4}{|c|}{$q \mathrm{~N}$} & \multicolumn{4}{|c|}{$\bar{q}$} & \multicolumn{4}{|c|}{$M_{\mathrm{q}}$} \\
\hline & \multicolumn{2}{|c|}{$\min$} & \multicolumn{2}{|c|}{$\max$} & \multicolumn{2}{|c|}{$\min$} & \multicolumn{2}{|c|}{$\max$} & \multicolumn{2}{|c|}{$\min$} & \multicolumn{2}{|c|}{$\max$} & \multicolumn{2}{|c|}{$\min$} & \multicolumn{2}{|c|}{$\max$} & \multicolumn{2}{|c|}{$\min$} & \multicolumn{2}{|c|}{$\max$} \\
\hline & or & 喼 & or & $\stackrel{\pi}{\stackrel{\pi}{2}}$ & $\sigma$ & 丞 & $\theta$ & $\stackrel{\frac{\pi}{2}}{\stackrel{2}{2}}$ & or & 氶 & or & 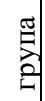 & or & 胥 & $\sigma$ & 営 & or & 脘 & $\sigma$ & 㞼 \\
\hline Пологе & $\tilde{n}$ & - & రి & $\begin{array}{l}\equiv \\
\equiv \\
\vec{\Xi}\end{array}$ & $n$ & 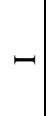 & 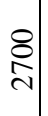 & $\stackrel{\Xi}{>}$ & $\stackrel{\infty}{+}$ & $\Xi$ & $\stackrel{\infty}{\stackrel{\text { }}{\hat{~}}}$ & 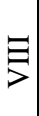 & $\begin{array}{l}\text { o } \\
\text { in }\end{array}$ & - & $\begin{array}{l}\infty \\
\stackrel{+}{ \pm}\end{array}$ & $\stackrel{\Xi}{>}$ & $\stackrel{\sim}{\sim}$ & - & $\underset{\Xi}{8}$ & 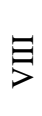 \\
\hline Крутопадаюче & $\Xi$ & - & $\stackrel{\overbrace{}}{6}$ & $\stackrel{\nabla}{>}$ & 6 & - & $\begin{array}{l}\text { ̊ } \\
\stackrel{1}{ } \\
\end{array}$ & 貝 & $\bar{n}$ & - & $\frac{\stackrel{ }{n}}{\sim}$ & 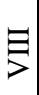 & $\frac{n}{n}$ & 一 & $\begin{array}{l}\stackrel{m}{\infty} \\
\stackrel{D}{\beth}\end{array}$ & $\underset{7}{\$}$ & $\stackrel{n}{\mathcal{f}}$ & - & $\stackrel{\curvearrowleft}{\stackrel{n}{\sim}}$ & $\stackrel{*}{>}$ \\
\hline
\end{tabular}

Примітка: * - за кількістю наявних даних неможливо визначити $\mathrm{M}_{\mathrm{q}}$ для груп VI $\div$ VIII

Проведені дослідження на прикладі статистичних моделей розподілу шахтопластів за чинниками, що прийняті при складанні «Каталогу...» [4] як такі, що впливають на пилоутворювальну здатність, дозволили оцінити достовірність вибору цих факторів і дати практичні рекомендації за прогнозом прояву інших небезпечних властивостей при веденні гірничих робіт. 
Висновки та перспективи подальших досліджень. Основні висновки, отримані в результаті проведених досліджень, зводяться до такого:

- виникнення аварійних ситуацій при веденні гірничих робіт обумовлено певним сполученням впливаючих факторів трьох блоків:

1. Елементний склад та фізико-хімічні властивості вугілля, що з'явилися в результаті метаморфічних перетворень пластів під впливом глибинних геологічних процесів в надрах Землі;

2. Гірничо-геологічні умови залягання вугільних пластів (потужність пласта, кут його падіння, наявність і розташування зближених пластів, властивості порід, газоносність і обводненність родовища);

3. Гірничотехнічні умови ведення гірничих робіт (способи розкриття родовища, системи розробки, технологія ведення гірничих робіт, схеми провітрювання виробок і шахти в цілому, засоби механізації основних і допоміжних процесів);

- труднощі вивчення впливу комплексу факторів трьох блоків на виникнення аварійних ситуацій полягає в неможливості повторного їх відтворення. Єдиний виняток становить пилоутворювальна здатність шахтопластів;

- практикою доведено зв'язок пилоутворювальної здатності з іншими небезпечними властивостями шахтопластів (ендогенна пожежонебезпека, виникнення вибухопожежонебезпечних ситуацій). Вивчивши комплекс факторів, що визначають процеси пилоутворення і встановивши співвідношення між показниками різних блоків, можна за аналогією розробити методику вибору факторів трьох блоків, співвідношення яких може призводити до прояву будь-якої небезпечної властивості шахтопласта при веденні гірничих робіт;

- в даний час не розроблена загальна науковообгрунтована методика вибору співвідношення факторів трьох блоків для прогнозу небезпечних властивостей шахтопластів при веденні гірничих робіт. Необхідність розробки такої методики для кожного виду прояву небезпечної властивості шахтопласта доведена на прикладі аналізу факторів, що визначають питоме пиловиділення. 3 прийнятих до аналізу факторів першого блоку (вихід летких речовин, вологість вугілля, вміст пилу у відбитому вугіллі) тільки вологість та вміст пилу достовірно визначають питоме пиловиділення. Механічна міцність вугілля та антрацитів офіційно належить до класифікаційних показників ступеня метаморфізму, але жоден 3 показників, що характеризують фізико-механічні властивості, не використаний при градації шахтопластів за пилоутворювальною здатністю. Фактори другого блоку (потужність пласта та кут його падіння) апріорі не можуть визначати питоме пиловиділення, яке залежить від факторів третього блоку (технологія виїмки вугілля і засобів механізації).

\section{Список використаної літератури:}

1. Правила ведення гірничих робіт на пластах, схильних до газодинамічних явищ : СОУ 10.1.00174088.011:2005 / О.М. Брюханов, О.В. Агафонов, А.В. Анцифферов та ін. - Чинний від 2005-12-01. К. : Мінвуглепром України, 2005. - 224 с.

2. Руководство по проектированию вентиляции угольных шахт. - К. : Основа, 1994. - 311с.

3. Руководство по предупреждению и тушению эндогенных пожаров на угольных шахтах Украины : КД 12.01.402:2000. - Донецк : НИИГД, 2000. - 216 с.

4. Руководство по борьбе с пылью в угольных шахтах. - М. : Недра, 1979. - 319 с.

5. Эндогенные пожары на угольных шахтах Донбасса. Предупреждение и тушение : инструкция : КД 12.01.401-96 / П.С. Пашковский, В.К. Костенко, В.П. Заславский и др. - Донецк : НИИГД, 1997. -68 с.

6. Дегазация угольных шахт. Требования к способам и схемы дегазации : СОУ10.1.0017-4088.011-2004. - К. : Минтопэнерго Украины, 2004. - 161 с.

7. Схеми та способи керування газовиділенням на виїмкових дільницях вугільних шахт : нормативний акт про охорону праці. - К. : Державний департамент промислової безпеки, охорони праці й гірничого нагляду, 2006. $-78 \mathrm{c}$

8. Инструкция по прогнозу и предупреждению внезапных прорывов метана из почвы горных выработок. МакНИИ. - 1987. - 29 с.

9. ГОСТ 17070-2014 Межгосударственный стандарт. Угли. Термины и определения. - М. : Стандартинформ, 2015. $-17 \mathrm{c}$

10. Peculiarities of using classification indicators of the coal metamorphism degree for predicting the hazardous coal seams properties / M.Antoshchenko, E.Filatieva, V.Yefimtsev, V.Tarasov // EDP Sciences. In E3S Web of Conferences. - 2020. - Vol. 201. DOI: 10.1051/e3sconf/202020101014.

11. ГОСТ 6382-2007 Межгосударственный стандарт. Топливо твердое минеральное. Методы определения выхода летучих веществ : ИСО 562-98, ИСО 5071-1-97. - М. : Стандартинформ, 2008. - 12 с.

12. ГОСТ 7303-90 Антрацит. Метод определения объемного выхода летучих веществ : СТ СЭВ 6768-89/ Государственный комитет СССР по управлению качеством продукции и стандартам. - М. : Издательство стандартов, 1990. $-7 \mathrm{c}$.

13. ГОСТ 1186-87 Угли каменные. Метод определения пластометрических показателей / Государственный комитет СССР по стандартам. - М. : Издательство стандартов, 2014. - 34 с. 
14. К вопросу определения классификационных показателей углей для установления опасных свойств шахтопластов / Н.И. Антощенко, В.Ю. Тарасов, Р.Г. Заика и др. // Геотехническая механика : межвед. сб. науч. тр. ИГТМ НАН Украины. - 2020. - № 152. - С. 149-159.

15. О некоторых особенностях взаимодействия между геомеханическими и физико-химическими процессами в угольных пластах Кузбасса / В.Н. Опарин и др. // Физико-технические проблемы разработки полезных ископаемых. - 2014. - № 2. - С. 3-30.

16. Балаєва Я.С. Розвиток уявлень щодо взаємозв'язку властивостей вугілля з найвищою теплотою згоряння та максимальною вологоємністю: автореф. дис. канд. техн. наук : 05.17 .07 / Я.С. Балаєва. - Харків : УХІН, 2018. $-20 \mathrm{c}$.

17. Взаимосвязь между технологическими свойствами углей и составом технического экстрактов / Л.Ф. Бутузова, Ш.М. Шакир, В.О. Кулакова, В.А. Колбаса // Вестник Донецкого технического университета. - 2016. - № 1 (1). - С. 13-20.

18. Федорова Н.И. Физико-химические свойства низкометаморфизованных длиннопламенных углей Кузбасса / Н.И. Федорова, А.Н. Заостровский, З.Р. Исмагилов // Вестник Кузбасского государственного технического университета. - 2015. - № 5 (111). - С. 126-129.

19. Эттингер И.Л. Распределение метана в порах ископаемых углей / И.Л. Эттингер, Н.В.Шульман. - М. : Наука, 1975. - $112 \mathrm{c}$.

20. Авгушевич И.В. Стандартные методы испытания углей. Классификации углей / И.В. Авгущевич, Е.И. Сидорук, Т.М. Броновец. - М. : Реклама мастер, 2019. - 576 с.

21. ГОСТ 25543-2013 Межгосударственный стандарт. Угли бурые, каменные и антрациты. Классификация по генетическим и технологическим параметрам. - М. : Стандарт-информ, 2014. - 19 c.

22. Forecasting propensity method of mine layers to endogenous fire hazard by metamorphic signs of coals transformation / V.Tarasov, M.Antoshchenko, Ye.Rudniev, A.Galchenko // Österreichisches Multiscience Journal. 2020. - № 32. - P. 67-74.

23. Ганова С.Д. К вопросу исследования состава углеводородных газов угольных пластов и пыли с целью возможного прогнозирования их потенциальной опасности / С.Д. Ганова, О.В. Скопинщева, О.Н. Исаев // Известия Томского политехнического университета. - 2019. - Т. 330. - № 6. - С. 109-115.

24. Кошовский Б.И. Пути повышения достоверности определения склонности углей к самовозгоранию / Б.И. Кошовский, П.С. Пашковский, В.В. Карасева // Уголь Украины. - 2008. - № 12. - С. 45-47.

25. Медведев Э.Н. Оценка пылеобразующей способности углей в ряду метаморфизма / Э.Н. Медведев, В.И. Саранчук, В.Н. Качан // Уголь Украины. - 1984. - № 8. - С. 32-33.

\section{References:}

1. Brjuhanov, O.M., Agafonov, O.V., Ancyferov, A.V. et al. (2005), Pravyla vedennja girnychyh robit na plastah, shyl'nyh do gazodynamichny javyshh, SOU 10.1.00174088.011:2005, Chynnyj vid 2005-12-01, Minvugleprom Ukrai'ny, K., 224 p.

2. Rukovodstvo po proektirovaniyu ventilyatsii ugol'nykh shakht (1994), Osnova, K., 311 p

3. Rukovodstvo po preduprezhdeniyu i tusheniyu endogennykh pozharov na ugol'nykh shakhtakh Ukrainy (2000), KD 12.01.402:2000, NIIGD, Donetsk, 216 p.

4. Rukovodstvo po bor'be s pyl'yu v ugol'nykh shakhtakh (1979), Nedra, M., 319 p.

5. Pashkovskii, P.S., Kostenko, V.K., Zaslavskii, V.P. et al. (1997), Endogennye pozhary na ugol'nykh shakhtakh Donbassa. Preduprezhdenie i tushenie, instruktsiya, KD 12.01.401-96, NIIGD, Donetsk, P. 68.

6. Degazatsiya ugol'nykh shakht. Trebovaniya k sposobam i skhemy degazatsii (2004), SOU10.1.0017-4088.0112004, Mintopenergo Ukrainy, K., 161 p.

7. Derzhavnyj departament promyslovoi' bezpeky, ohorony praci j girnychogo nagljadu (2006), Shemy ta sposoby keruvannja gazovydilennjam na vyi'mkovyh dil'nycjah vugil'nyh shaht, normatyvnyj akt pro ohoronu praci, K., 78 p.

8. Instruktsiya po prognozu i preduprezhdeniyu vnezapnykh proryvov metana iz pochvy gornykh vyrabotok (1987), MakNII, 29 p.

9. GOST 17070-2014 Mezhgosudarstvennyi standart. Ugli. Terminy i opredeleniya (2015), Standartinform, M., 17 p.

10. Antoshchenko, M., Filatieva, E., Yefimtsev, V. and Tarasov, V. (2020). «Peculiarities of using classification indicators of the coal metamorphism degree for predicting the hazardous coal seams properties», EDP Sciences. In E3S Web of Conferences, Vol. 201, doi: 10.1051/e3sconf/202020101014.

11. GOST 6382-2007 (2008), Mezhgosudarstvennyi standart. Toplivo tverdoe mineral'noe. Metody opredeleniya vykhoda letuchikh veshchestv, ISO 562-98, ISO 5071-1-97, Standartinform, M., 12 p.

12. Gosudarstvennyi komitet SSSR po upravleniyu kachestvom produktsii i standartam (1990), GOST 7303-90 Antratsit. Metod opredeleniya ob"emnogo vykhoda letuchikh veshchestv, ST SEV 6768-89, Izdatel'stvo standartov, M., 7 p.

13. Gosudarstvennyi komitet SSSR po standartam (2014), GOST 1186-87 Ugli kamennye. Metod opredeleniya plastometricheskikh pokazatelei, Izdatel'stvo standartov, M., $34 \mathrm{p}$

14. Antoshchenko, N.I., Tarasov, V.Yu., Zaika, R.G. et al. (2020), «K voprosu opredeleniya klassifikatsionnykh pokazatelei uglei dlya ustanovleniya opasnykh svoistv shakhtoplastov», Geotekhnicheskaya mekhanika, mezhved. sb. nauch. tr. IGTM NAN Ukrainy, No. 152, pp. 149-159.

15. Oparin, V.N. et al. (2014), «O nekotorykh osobennostyakh vzaimodeistviya mezhdu geomekhanicheskimi i fizikokhimicheskimi protsessami v ugol'nykh plastakh Kuzbassa», Fiziko-tekhnicheskie problemy razrabotki poleznykh iskopaemykh, No. 2, pp. 3-30. 
16. Balajeva, Ja.S. (2018), Rozvytok ujavlen' shhodo vzajemozv'jazku vlastyvostej vugillja z najvyshhoju teplotoju zgorjannja ta maksymal'noju vologojemnistju, Abstract of Ph.D. dissertation, 05.17.07, UHIN, Harkiv, 20 p.

17. Butuzova, L.F., Shakir, Sh.M., Kulakova, V.O. and Kolbasa, V.A. (2016), «Vzaimosvyaz' mezhdu tekhnologicheskimi svoistvami uglei i sostavom tekhnicheskogo ekstraktov», Vestnik Donetskogo tekhnicheskogo universiteta, No. 1 (1), pp. 13-20.

18. Fedorova, N.I., Zaostrovskii, A.N. and Ismagilov, Z.R. (2015), «Fiziko-khimicheskie svoistva nizkometamorfizovannykh dlinnoplamennykh uglei Kuzbassa», Vestnik Kuzbasskogo gosudarstvennogo tekhnicheskogo universiteta, No. 5 (111), pp. 126-129.

19. Ettinger, I.L. and Shul'man, N.V. (1975), Raspredelenie metana v porakh iskopaemykh uglei, Nauka, M., 112 p.

20. Avgushevich, I.V., Sidoruk, E.I. and Bronovets, T.M. (2019), Standartnye metody ispytaniya uglei. Klassifikatsii uglei, Reklama master, M., 576 p.

21. GOST 25543-2013 (2014), Mezhgosudarstvennyi standart. Ugli burye, kamennye i antratsity. Klassifikatsiya po geneticheskim i tekhnologicheskim parametram, Standart-inform, M., $19 \mathrm{p}$.

22. Tarasov, V., Antoshchenko, M., Rudniev, Ye. and Galchenko, A. (2020), «Forecasting propensity method of mine layers to endogenous fire hazard by metamorphic signs of coals transformation», Österreichisches Multiscience Journal, No. 32, pp. 67-74.

23. Ganova, S.D., Skopintseva, O.V. and Isaev, O.N. (2019), «K voprosu issledovaniya sostava uglevodorodnykh gazov ugol'nykh plastov i pyli s tsel'yu vozmozhnogo prognozirovaniya ikh potentsial'noi opasnosti», Izvestiya Tomskogo politekhnicheskogo universiteta, Vol. 330, No. 6, pp. 109-115.

24. Koshovskii, B.I., Pashkovskii, P.S. and Karaseva, V.V. (2008), «Puti povysheniya dostovernosti opredeleniya sklonnosti uglei k samovozgoraniyu», Ugol' Ukrainy, No. 12, pp. 45-47.

25. Medvedev, E.N., Saranchuk, V.I. and Kachan, V.N. (1984), «Otsenka pyleobrazuyushchei sposobnosti uglei v ryadu metamorfizma», Ugol' Ukrainy, No. 8, pp. 32-33.

Руднєв Євген Сергійович - кандидат технічних наук, доцент Східноукраїнського національного університету імені Володимира Даля.

Наукові інтереси:

- прогноз небезпечних властивостей вугільних шахтопластів;

- охорона праці у гірництві.

Гальченко В'ячеслав Анатолійович - аспірант Східноукраїнського національного університету імені Володимира Даля.

Наукові інтереси:

- інформаційні технології;

- охорона праці у гірництві;

- прогноз небезпечних властивостей вугільних шахтопластів;

- штучний інтелект у промисловості.

Філатьева Ельвіра Миколаївна - старший викладач Східноукраїнського національного університету імені Володимира Даля.

Наукові інтереси:

- охорона праці у гірництві;

- механіка зрушення гірничих порід;

- прогноз газовиділення.

Антощенко Микола Іванович - доктор технічних наук, професор Східноукраїнського національного університету імені Володимира Даля.

Наукові інтереси:

- розробка вугільних родовищ;

- охорона праці у гірництві;

- механіка зрушення гірничих порід;

- прогноз газовиділення;

- прогноз небезпечних властивостей вугільних шахтопластів.

Стаття надійшла до редакції 18.10.2021. 